\title{
Aanwezigheid van werk van Hugo de Groot in Debrecen*
}

\begin{abstract}
This paper discusses the occurrence of books of the Dutch humanist Hugo Grotius (1583-1645) in the Main Library of the Debrecen Reformed Theological University (founded in 1538). The results of this research are compared with the results of a similar research project conducted some years earlier in Olomouc and Prague. A complete list of works of Grotius in Debrecen is presented is in the annex.
\end{abstract}

Keywords: Hugo Grotius, early modern books, Debrecen, Olomouc, Prague, history of ideas

\section{Inleiding}

In de jaren 2004 en 2005 voerde een groepje neerlandici van de universiteiten van Wrocław, Praag en Olomouc onder leiding van Stefan Kiedroń en met assistentie van wijlen Karel Bostoen uit Leiden een pilotproject uit om vast te stellen hoeveel oude drukken uit de periode 1500-1800 aanwezig zijn in de huidige collecties Oude Drukken van historische bibliotheken in Brno, Olomouc, Praag en Wrocław.

Kort daarvoor werd door de auteur van dit artikel een 'pre-pilot' uitgevoerd om de aanwezigheid van werken van de humanist Hugo de Groot vast te stellen in de historische bibliotheken te Praag (Národní knihovna "Klementinum" - de Nationale Bibliotheek) en Olomouc (Vědecká knihovna v Olomouci - de Weten-

* Dit artikel is het resultaat van ondersteuning in het project Rozvojový projekt MŠMT $\check{C} R$ pro rok 2016 - podpora zahraničnich mobilit akademických pracovniků FF UP (Ontwikkelingsproject ministerie van onderwijs van Tsjechië voor 2016 - ondersteuning van buitenlandse mobiliteit van academici van de FF UP). 
schappelijke Bibliotheek). De resultaten van dit onderzoek zijn gepubliceerd in het tijdschrift Grotiana (Engelbrechtová 1999/2000). Inmiddels zijn er verschillende andere (deel)onderzoeken uitgevoerd om een beter idee te krijgen van de impact van de ideeën van Hugo de Groot in Centraal-Europa.

Het is fysiek onmogelijk om álle bibliotheken in Centraal-Europa na te gaan op de aanwezigheid van werken van Hugo de Groot. Daarom is een keus gemaakt uit representatieve bibliotheken die zich bevinden op het gebied van voormalig Oostenrijk-Hongarije. Het ligt in de bedoeling om oude universiteitsbibliotheken na te gaan, de voormalige keizerlijke bibliotheek te bekijken en enkele meer gespecialiseerde bibliotheken te onderzoeken. In de praktijk betekent dit dat het onderzoek naar Grotiana zal worden uitgevoerd in de Oostenrijkse Nationale Bibliotheek (opvolgster van de voormalige Keizerlijke Hofbibliotheek), in de universiteitsbibliotheken van Praag, Krakau en Olomouc (de drie oudste nog bestaande universiteitsbibliotheken), de universiteitsbibliotheek van Wrocław (de kern van het huidige fonds oude drukken bestaat uit de oude stadsbibiotheek) en tenslotte twee van huis uit kerkelijk en wetenschappelijk-theologisch georiënteerde bibliotheken, namelijk de zgn. Oude Bibliotheek van het Aartsbisschoppelijk Kasteel te Kroměříž (Tsjechië) en de Grote Bibliotheek van het Gereformeerd College te Debrecen. ${ }^{1}$

Het onderzoek in Praag en Olomouc is, zoals hierboven gemeld, al enkele jaren geleden uitgevoerd. De bestanden van de bibliotheek in Olomouc zijn kort geleden opnieuw aan een kritische analyse onderworpen die binnenkort zal worden gepubliceerd. Ditmaal is ook gekeken naar de aanwezigheid van verwijzingen naar Grotius in collegemateriaal van hoogleraren (Engelbrechtová 2017). Het onderzoek in Wrocław is nog gaande, dat in Kroměříž is gepland voor 2018 en als laatste zullen de bestanden van de Oostenrijkse Nationale Bibliotheek in Wenen worden onderzocht.

Een van de deelonderzoeken betrof vorig jaar de bestanden van de Debreceni Református Kollégium Nagykönyvtára (Grote Bibliotheek van het Gereformeerd College van Debrecen) in de Hongaarse stad Debrecen. ${ }^{2}$ De resultaten van dit onderzoek zijn opgenomen in de bijlage bij dit artikel en worden in het artikel zelf geconfronteerd met de eerder vastgestelde resultaten uit Praag en Olomouc.

${ }^{1}$ Österreichische Nationalbibliothek, Wenen; Národní knihovna v Praze, Praag; Biblioteka Jagiellońska Uniwersytetu Jagiellońskiego, Krakau; Vědecká knihovna v Olomouci, Olomouc; Biblioteka Uniwersytecka we Wrocławiu, Wrocław; Zámecká knihovna Arcibiskupského zámku v Kroměříži, Kroměříž; Debreceni Református Kollégium Nagykönyvtára, Debrecen.

${ }^{2}$ Hier past een oprecht woord van dank aan doc. dr. Gábor Pusztai, dr. Réka Bozzay en dr. Róbert Oláh die buitengewoon behulpzaam waren, zodat het hele onderzoek in één enkele week kon worden gedaan en er veel meer boeken tegelijk op tafel konden komen dan gebruikelijk is. Dr. Réka Bozzay was bovendien zeer behulpzaam bij de identificatie van verschillende Hongaarse bezitters van Grotiana, m.n. waar het de vele pastores uit allerlei kleinere en grotere plaatsen betreft. Dank is de auteur ook verschuldigd aan beide anonieme reviewers. 


\section{De positie van Hugo de Groot}

De drie humanisten Desiderius Erasmus (1469-1536), Hugo de Groot (1583-1645) en Benedictus (Baruch) de Spinoza (1632-1677) zijn ontegenzeggelijk internationaal de bekendste schrijvers van Nederlandse herkomst, elk op zijn eigen wijze. Zij hebben gemeen dat zij - meestal in het Latijn, de internationale taal van vóór de achttiende eeuw - fundamentele werken hebben geschreven die in hun respectievelijke vakgebieden de basis hebben gelegd voor de wetenschap en modern denken.

Van de drie genoemde personen was Hugo de Groot, of Grotius zoals hij internationaal bekend is, de enige die ook belangrijk werk in zijn moedertaal heeft geschreven. Hoewel hij vooral vermaard is als grondlegger van het internationaal recht (zijn juridische werk is tevens de reden dat er nog steeds edities van zijn werken uitkomen en dat dit werk nog altijd wordt bestudeerd), kunnen we stellen dat zijn werk twee belangrijke aandachtspunten kende. Dat waren het reeds genoemde juridische werk en daarnaast zijn theologische werk. Grotius was zelf overigens, geheel in de geest van zijn tijd, geneigd om dat laatste als belangrijker te beschouwen. Op beide gebieden was het zijn bedoeling om door zoveel mogelijk fundamentele gemeenschappelijke overeenkomsten te vinden, de oorzaken van twisten weg te nemen.

Deze doelstelling is redelijk bereikt in zijn internationale werk. Op basis van de tamelijk eenvoudige regels die Grotius opstelde in zijn drie juridische geschriften De jure praedae (Over het buitrecht, handschrift 1607, druk 1868), Mare liberum (De vrije zee, 1609) $)^{3}$ en De jure belli ac pacis (Van het recht van oorlog en vrede, 1625) is het internationale recht, inclusief het volkenrecht en oorlogsrecht ontstaan. Het is hem echter niet gelukt op theologisch gebied. Grotius was een overtuigd irenist, iemand die ervan uitgaat dat de verschillende religies zoveel mogelijk in vrede moeten leven. De overtuiging dat het christendom weliswaar de ware religie is, maar dat je andersgelovigen alleen met argumenten echt kunt overtuigen en dat de meeste godsdiensten inherent hetzelfde doel hebben - een betere samenleving - lagen ten grondslag aan zijn geschriften op dit terrein. De belangrijkste ervan zijn De veritate religionis christianae (Over het bewijs van de ware godsdienst, 1627) ${ }^{4}$, Via ad pacem ecclesiasticam (De weg naar de kerkelijke vrede, 1642) en De imperio summarum potestatarum circa sacra (Over de macht van heersers in kerkelijke aangelegenheden, handschrift 1617, druk 1647). Deze werken zijn in vrijwel alle belangrijkere buitenlandse bibliotheken terug te vinden, hoewel in elk geval De jure belli ac pacis en al Grotius' theologische werken als 'heretisch' op de kerkelijke index stonden (Index 1758: 117).

${ }^{3}$ Nederlandse versie Vrye zeevaert, 1614.

${ }^{4}$ Latijnse bewerking door Grotius zelf van het Nederlandse origineel Bewys van den waren Godsdienst, 1622. 


\section{Doelstelling van het onderzoek}

Onderzoek naar de aanwezigheid van oude drukken in historische collecties heeft niet alleen zin voor 'bibliofielen', maar geeft ons, vooral in combinatie met zgn. 'proveniënties', registraties van eerdere bezitters, een interessant inzicht in de verspreiding van ideeën en in hoeverre de bezitters werkelijk kennis namen van bepaalde werken.

Bij een belangrijke, maar bepaald niet onomstreden humanist als Grotius geeft het een inzicht in welke werken men inderdaad las. In het navolgende zal worden getoond dat de accenten in de diverse intellectuele collecties onderling soms grote verschillen vertonen die te maken hebben met de gebruikers. Het onderzoek draagt dus bij aan wat sinds de Verlichting als Geistesgeschichte en sinds recent als Wissensgeschichte bekend staat (Strelka 1990).

\section{Karakter van de onderzochte bibliotheken}

De Nationale Bibliotheek te Praag en de Wetenschappelijke Bibliotheek te Olomouc zijn beide in de zestiende eeuw gesticht als centrale studiebibliotheken van de Jezuïetenuniversiteiten in beide plaatsen (Engelbrechtová 1999/2000: 110 111, 114-116; Kiedroń 2015: 25-26). Deze universiteiten fungeerden tevens als de landelijke universiteiten van het koninkrijk Bohemen en de markgraafschap Moravië. De collecties van beide bibliotheken ondervonden invloed van de kerkelijke politiek van keizerin Maria-Theresia die de Jezuïetenorde in 1773 liet opheffen en van haar zoon keizer Jozef II die tussen 1781 en 1784 alle "onnutte kloosters" liet opheffen. In Bohemen betrof dit 70 en in Moravië 34 kloosters. De boekencollecties werden primair toegewezen aan de inmiddels tot staatsuniversiteiten omgevormde voormalige Jezuïetenuniversiteiten (Čornejová 2001; Glonek 2016a, Glonek 2016b). Aangezien beide bibliotheken onmogelijk de tienduizenden extra boeken konden opnemen die het gevolg waren van deze actie, werden de vele doubletten veelal als oud papier of in speciale boekenveilingen verkocht. Beide universiteiten ontvingen in de negentiende eeuw grote boekenschenkingen van veelal adellijke weldoeners of voormalige hoogleraren en beide kregen na de Tweede Wereldoorlog collecties van in beslag genomen bibliotheken van voormalige Duitstalige instellingen, kloosters of adellijke landgoederen. In veel gevallen werden adellijke en kerkelijke collecties na het herstel van de parlementaire democratie in 1989 weer teruggegeven aan de oorspronkelijke bezitters.

Het karakter van de Grote Bibliotheek in Debrecen verschilt. Hoewel het huidige gebouw van het College pas in de jaren 1803-1813 werd gebouwd, werd de bibliotheek al direct bij de grondlegging van het Gereformeerde College in 1538 gesticht. Dit College werd in 1549 Calvinistisch en is dat tot op de dag van 
vandaag gebleven. Daarmee is het één van de oudste ononderbroken bestaande protestantse wetenschappelijke instellingen ter wereld.

Anders dan de bibliotheken in Praag en Olomouc onderging de Grote Bibliotheek in Debrecen minder radicale ingrepen. De stad Debrecen werd in 1555 door de Turken bezet, maar bleef liggen precies aan de grens tussen het Habsburgse Opperhongarije en het Vorstendom Transsylvanië. Transsylvanië was een vazalstaat van het Osmaanse Rijk, de vorsten waren merendeels protestants maar de staat zelf erkende sinds 1568 vier christelijke religies (katholiek, calvistisch, luthers en unitarisch). Dankzij tribuutbetalingen bleef de stad vrij van Turkse bezetting, al was de stad tot 1660 onderdeel van het Vorstendom Transsylvanië. In de navolgende jaren was de status van de stad onduidelijk. Zij werd tweemaal, in 1675 en 1686, door keizerlijke troepen verwoest. In 1693 verleende keizer Leopold I aan Debrecen de titel van Koninklijke Stad en in 1699 kwam heel Hongarije na de Vrede van Karlowitz aan de Habsburgers.Tijdens de zogeheten Kuruzenopstand in de jaren 1703-1711 werd Debrecen in 1707 door de keizerlijke troepen bezet, waarbij het ook tot schade aan het College en de bibliotheek kwam. In latere oorlogen liep de bibliotheek geen schade op. De meeste boeken van de bibliotheek zijn afkomstig van aankoop, van schenkingen van eigen hoogleraren of - met name in de negentiende eeuw - uit schenkingen van adellijke mecenassen.

De gestadige, afgezien van de overgangsperiode tussen Osmaans en Habsburgs bewind eind zeventiende eeuw, feitelijk ononderbroken ontwikkeling van de bibliotheek in Debrecen en het protestantse (calvinistische) karakter zijn twee belangrijke verschillen met het karakter van de beide eerder onderzochte bibliotheken in Praag en Olomouc. Hierbij moet als extra punt nog worden aangetekend dat het werk van Hugo de Groot niet alleen voor de katholieke kerk problematisch was, zie de reeds genoemde Index. Het remonstrantisme lag in de Calvinistische kerk van Hongarije eveneens moeilijk. De Synode van Nyírbátor besloot in 1631 dat alleen zulke kandidaten voor studie in het buitenland zouden worden aanbevolen die zich zouden hoeden voor sekten en opinies die de Helvetische geloofsbelijdenis weerspreken. Van studenten die naar Leiden gingen om te studeren werd verlangd dat zij een formulier tekenden, waarin zij beloofden zich voor remonstrantisme te hoeden (Bozzay 2017). Grotius was dus als feitelijk remonstrants theoloog niet op voorhand aanvaardbaar voor het Gereformeerd College in Debrecen. En toch treffen we in alle drie de bibliotheken een ruime keuze uit de werken van Grotius aan, zij het met verschillende accenten.

In het navolgende zullen eerst de resultaten van de bibliotheken in Praag en Olomouc kort worden herhaald om vervolgens dieper in te gaan op die in Debrecen. 


\section{Classificatie}

Bij internationaal erkende en veelvuldig bestudeerde auteurs als Hugo de Groot heeft de onderzoeker het voordeel dat er vaak standaard bibliografieën en classificaties bestaan. Het standaardoverzicht van zijn werk is de Bibliographie des écrits imprimés de Hugo Grotius van Jacob ter Meulen en Pieter J.J. Diermanse uit 1950 (hierna TMD). Deze bibliografie behandelt systematisch alle door Hugo de Groot geschreven werken met vermelding van voor zover bekend alle latere edities. ${ }^{5}$

De werken van De Groot zijn zo goed als alle aanwezig in de bibliotheek van het Vredespaleis in Den Haag. Deze zijn geclassificeerd door Arthur C. Eyffinger in The Grotius Collection at the Peace Palace. A Concise Catalogue (Eyffinger 1983). Deze classificatie omvat:

- Dichtwerken: Poemata collecta, Christus patiens, de vertaling van Martin Opitz van De Bewys van den waren Godsdienst.

- Filosofisch werk: Limenheuretica.

- Filologisch werk (vooral edities): Anthologia Graeca, De fato, De studiis instituendis, Euripides, Lucanus, Martianus Capella, Menander, Plutarchus, Tacitus.

- Internationaal recht: De jure belli ac pacis, De mare libero, De jure praedae, Mare liberum.

- Historisch werk: Annales et Historiae de rebus Belgicis, De antiquitate reipublicae, De origine gentium Americanarum, Grollae obsidio, Historia Gotthorum.

- Jurisprudentie: Florum sparsio.

- Politiek-religieuze tractaten: Apologeticus, De imperio summaru potestatarum.

- Theologisch werk: Annotationes ad Vetus Testamentum, De veritate religionis christianae, Consultationem Cassandri annotate, Via ad pacem ecclesiastiam, Opera omnia theologica.

- Brieven: Clavis epistolarum, Epistolae ad Gallos, Epistolae ad Crellium.

- Anthologieën.

- Mengelwerk (meestal werk over of tegen Grotius, waarin ook zijn eigen stukken zijn opgenomen): Appendix ad Catholicum orthodoxum (...) Cum scriptis adversariis Hugonis Grotii et Andreae Riveti (1644), Georg Horn, Dissertatio ... ad Grotii De jure belli ac pacis (1744), Johan Slichting, In Grotii votum pro pace (1685), I.B. Wernher, Analecta iuris naturae et gentium (1721).

${ }^{5}$ De door mij gebruikte editie uit 1995 is een ongewijzigde reprografische herdruk. Hierbij moet overigens worden opgemerkt dat 'TMD' niet altijd zonder voorbehoud dient te worden gevolgd, zoals Osler 2016: 11 duidelijk laat zien. 


\section{Grotiana in Praag}

In het Klementinum zijn er 108 titels van werken van Grotius van voor 1800 aanwezig. Het wekt geen verbazing dat de grote meerderheid daarvan juridisch werk (42 stuks) en theologisch werk (20 stuks) betreft, waarbij De jure belli ac pacis met 20 Latijnse edities en 6 Franse en 2 Duitse vertalingen verreweg het populairste werk is.

Bij 52 titels $(48,1 \%)$ is de herkomst van het boek bekend. Zeven ervan behoorden tot de Bibliotheca Maior van het Klementinum, met andere woorden ze zijn afkomstig van de Praagse universiteit. Dit betreft de Opera omnia theologica, de De veritate religionis christianae, van het juridische werk een complete editie van De jure belli ac pacis, nog een compendium uit dit werk voor schoolgebruik, de Grollae obsidio en de Florum sparsio. De bibliotheek kreeg in 1726 een grote boekengift van Franz Leopold Graf Sternberg (1680-1745) met vooral juridische en medische boeken, in 1749 schonk keizerin Maria-Theresia ruim 4000 doubletten van de keizerlijke bibliotheek aan het Klementinum en tenslotte liet bisschop Johann Rudolf Graf Špork (1695-1759) bij testament een groot deel van zijn bibliotheek aan het Klementinum na. Op deze wijze kwamen de meeste overige exemplaren van De jure belli ac pacis in bezit van de bibliotheek. Uit de adellijke schenkingen van de Vorsten von Wallenstein in 1776 en van Franz-Joseph Graf Kinský (1739-1805) die in 1777 voorstelde om de voormalige Jezuïetenbibliotheek te verenigen met de Universiteitsbibliotheek van het zgn. Novum Carolinum tot een Openbare Keizerlijke en Koninklijke Bibliotheek - het feitelijk begin van de huidige bibliotheek - werdener nog meer exemplaren van De jure belli ac pacis in de collectie opgenomen. Het theologische werk is merendeels afkomstig uit onder Josef II opgeheven kloosters: de Jezuïeten in Litoměřice, de Praagse Ongeschoeide Karmelieten, de Premonstraten in Chotěšov en de Capucijners van Klášter Hradiště nad Jizerou. Uit een schenking gedaan door Franz Zdenko von Lobkowitz (1858-1938), de laatste regerende vorst uit het geslacht in Roudnice nad Labem, kwam de bibliotheek van dat slot aan het Klementinum, waar deze bibliotheek met 65.000 banden een aparte afdeling vormt. Negen banden hiervan zijn Grotiana: filologisch werk (De fato, Lucanus, Martianus Capella), een Franse en twee Duitse vertalingen van De jure, De mare libero, Apologeticus en Annales Historiae. In Praag ligt dus duidelijk de nadruk op de juridische werken.

\section{Grotiana in Olomouc}

De Wetenschappelijke Bibliotheek in Olomouc is na het Klementinum de belangrijkste bibliotheek van Tsjechië. In essentie gaat ook deze bibliotheek terug op de oude universiteitsbibliotheek, gesticht in 1566 bij het toenmalige jezuïetencollege dat in 1573 een universitaire status kreeg, waarmee de tweede oudste universiteit 
van Tsjechië werd opgericht. In deze bibliotheek die veel kleiner is, zijn er 41 werken van Grotius van voor 1800 aanwezig. In 31 gevallen $(75,6 \%)$ is een proveniëntie aanwezig.

Aangezien de oorspronkelijke collectie in de jaren 1642-1650 goeddeels als oorlogsbuit door de Zweden naar Uppsala en Turku is verscheept, maken de boeken die eind achttiende eeuw dankzij de opheffing van kloosters werden verkregen een veel groter deel van het boekenbestand uit. Bovendien kreeg de universiteit van Olomouc begin negentiende eeuw net als het Klementinum grote legaten van adellijke families en werden er na 1945 collecties van in beslag genomen adellijke goederen aan toegevoegd.

De samenstelling van de Grotiana is daardoor gelijkmatiger verspreid en er zijn veel minder doublures. Ook te Olomouc is er onder de werken van Grotius niets in het Nederlands aanwezig en ook hier is De jure belli ac pacis met 7 Latijnse edities, 2 Franse en 2 Duitse vertalingen het populairste werk, gevolgd door de Grotius-editie van Lucanus (3 edities). Slechts twee titels zijn afkomstig uit de oude universiteitsbibiotheek, een editie van de Pharsalia van Lucanus en een exemplaar van De jure belli ac pacis, beide zijn vermeld in de tweede bibliotheekcatalogus van 1740. In Olomouc is de helft van de Grotiana uit bezit van door Jozef II opgeheven kloosters, voornamelijk complete edities van Grotius' theologische werken die hadden toebehoord aan verlichte abten van het Premonstratenzer klooster Louka bij Znojmo en het Cisterciënser klooster in Žd'ár nad Sázavou. Men bleek in deze kloosters overigens ook interesse in het juridisch werk van Grotius te hebben, in Žd'ár bezat men zowel een goede Latijnse editie als een Duitse vertaling. Dit hangt vermoedelijk samen met het feit dat de verlichte abt Václav Vejmluva (1670-1738) in 1724 in zijn klooster een speciale academie voor zoons uit adellijke families had opgericht, waar o.a. rechten en ingenieurswetenschappen werden onderwezen. Veel juridisch werk van Grotius was ook in Olomouc afkomstig uit adellijk bezit - schenkingen door de barons Locella begin negentiende eeuw en uit het na de Tweede Wereldoorlog geconfisceerde Jemnice in Zuid-Moravië dat had toebehoord aan de vorsten Palavicini.

\section{Grotiana in Debrecen}

Hierboven is al aangegeven dat het karakter van de Grote Bibliotheek in Debrecen wezenlijk verschilt van dat van beide universiteitsbibliotheken in Praag en Olomouc. Het College is van oudsher primair gericht geweest op theologisch opleiden van toekomstige calvinistische predikanten. Afgezien van beschadigingen tijdens de sterk wisselende frontbewegingen in de periode 1675-1707 liepen stad en bibliotheek weinig schade op. Er is sprake van een gestage ontwikkeling die bijna vijf eeuwen lang min of meer ononderbroken werd voortgezet. 
Hugo de Groot behoorde ontegenzeggelijk tot de belangrijkste denkers van zijn tijd. Maar als een van de feitelijke voormannen van de remonstranten was vooral zijn theologische gedachtengoed niet zonder voorbehoud acceptabel voor de rechtzinnige institutie die niet voor niets de bijnaam A Kálvinista Róma, het Calvinistische Rome, op de stad drukte (Györi 2013: 166). Zoals hierboven vermeld, werden de remonstrantse ideeën in navolging van de Dordtse Synode van 1618/19 ook in Hongarije door de Synode van Nyírbátor van 1631 uitdrukkelijk veroordeeld. Dit maakte het tamelijk onzeker of er van het werk van de irenische denker in Debrecen veel aanwezig zou zijn.

Dat viel mee: met 52 aanwezige titels ${ }^{6}$ scoort Debrecen midden tussen Praag en Olomouc. Als we ons realiseren dat de bibliotheek veel kleiner is dan die van Olomouc en ongeveer 35.000 oude drukken bezit, waarvan 146 wiegedrukken zijn, is dit zelfs een relatief grote collectie Grotiana. $^{7}$ In 42 van de Grotiana $(79,2 \%)$ is een proveniëntie aanwezig, waarbij deze in twee gevallen ${ }^{8}$ vernietigd is door de oorspronkelijke notitie grondig door te strepen en soms zelfs weg te knippen. Iets minder dan de helft van de Grotiana betreffen filologisch en juridisch werk, in 30 gevallen gaat het om theologisch werk. Dit uit zich ook duidelijk in de preferenties: hier is De veritate religionis Christianae met liefst 11 Latijnse edities, 1 Franse en 1 Hongaarse vertaling het populairste werk van De Groot. Zijn De jure belli ac pacis komt hier niet verder dan 7 Latijnse edities, 1 Franse en 1 Duitse vertaling.

Gezien de geschiedenis van de bibliotheek is het niet verwonderlijk dat vrijwel alle proveniënties hoogleraren, studenten of bibliothecarissen van de Grote Bibliotheek betreft. Vaak zijn de personen niet met zekerheid identificeerbaar, bijvoorbeeld in gevallen dat deze István Nagy, Mihály Kis of János Buda heten, in Hongarije vaak voorkomende combinaties.

\section{Enkele bezitters van Grotiana}

In 13 gevallen bestaat de proveniëntie uit registratie door de dienstdoende bibliothecaris. ${ }^{9}$ Deze deed uiteraard gewoon zijn plicht. Er is wel een duidelijk verschil met de situatie in de bibliotheken van Olomouc en Praag - daar komen we nooit te

${ }^{6}$ In de bijlage is een complete lijst aanwezig. De nummers 6 en 31 zijn niet te vinden.

7 Ter vergelijking, het Klementinum in Praag heeft ongeveer 200.000 oude drukken, waarvan 4200 wiegedrukken, en de Wetenschappelijke Bibliotheek in Olomouc ongeveer 65.000 oude drukken, waarvan ruim 2000 wiegedrukken.

${ }^{8}$ Nrs. 12 en 23.

${ }^{9}$ Nrs. 7 (Dániel Oroszi, 1773), 12 (Lajos Farkas, 1826), 13 (András Ormós, 1775), 14 en 17 (Miklós Menyhárt, 1771 en 1770), 19 (Pál Szélesi, 1786), 22 (Sámuel Mindszenti, 1777), 39 en 47 (József Milesz, 1768), 42 (György Szikszai), 45 (Ádám Balogh), 46 (Sámuel Nagy), 51 (József Péczely). 
weten, wie de 'registrator' was. De bibliotheek in Debrecen werd vanaf 1735 officieel bestuurd door een bibiothecarius praepositus, bijgestaan door verschillende bibliothecarii ordinarii die het feitelijke werk deden. De functie van 'opperbibliothecaris' werd meestal vervuld door een belangrijke hoogleraar (Györi 2006: 118-119). Dat deze functie zeker niet uitsluitend een erebaantje was, blijkt uit de proveniënties. Van de zes opperbibliothecarissen die elkaar in de achttiende eeuw afwisselden, treffen we er drie aan als personen die Grotiana hebben aangeschaft, hetzij voor de eigen privébibliotheek of rechtstreeks voor de Grote Bibliotheek. In chronologische volgorde waren dat György Maróthi (1715-1744) die van 1738 tot zijn ontijdige dood in 1744 de tweede opperbibliothecaris was, István Hatvani (1718-1786), derde opperbibliothecaris van 1744 tot 1760, en Miklós Sinai (1730-1808), vierde opperbibliothecaris van 1760 tot 1791.

Van hen was Maróthi verreweg de belangrijkste. ${ }^{10}$ Maróthi was afkomstig uit een rijke patriciërsfamilie uit Debrecen en deed in de jaren 1732-1738 zijn peregrinatio academica, in de jaren 1735 en 1736 in Groningen, Den Haag, Leiden, Utrecht en Amsterdam, waar hij systematisch colleges in de physica volgde. Hij leerde behalve de traditionele theologische talen Hebreeuws, Latijn en Grieks ook perfect Frans, Duits, Nederlands en Engels. Na terugkomst in Debrecen werd hij hoogleraar geschiedenis, wiskunde, Latijn en rethorica en schonk in zijn functie van opperbibliothecaris de omvangrijke collectie boeken die hij op zijn reizen had verzameld aan de bibliotheek. Tot deze boeken behoorden vier Grotiana: ${ }^{11}$ een editie van Theocritus, een bij Blaeu uitgegeven Annales et Historiae de rebus Belgicis, het commentaar Florum sparsio ad Jus Justinianaeum en de briefwisseling van Grotius met de humanist en pacifist Matthias Bernegger (1582-1640). In alle gevallen ging het om uitgaven in het Latijn, interessant is dat van twee boeken bekend is, waar Maróthi ze had gekocht: in Basel $(1735$, nr. 1) en in Bern (1736, nr. 22), dus voorafgaand aan en na zijn verblijf in Nederland.

Hoewel Maróthi slechts kort leefde, had hij grote invloed op modernisering van het College van Debrecen. Hij was de eerste grote muziektheoreticus in Hongarije, richtte op basis van zijn Zwitserse ervaringen in 1739 een universiteitskoor op en voerde polyfone zangwijzen voor de psalmen in, vanuit Calvinistische optiek een tamelijk revolutionaire nieuwigheid. Hij was een voorvechter van de introductie van de moderne talen Frans en Engels in het academisch onderwijs en van de moedertaal Hongaars in het basisonderwijs. Zijn Nederlandse ervaringen gebruikte hij voor modernisering van het onderwijs in de natuurwetenschappen. Zo liet hij in 1742 naar Leids voorbeeld een fysisch auditorium inrichten en liet in 1743 het observatorium van Debrecen bouwen.

${ }^{10}$ Gegevens op basis van Barcza 1988: 91-96, Zoványi 1977 nr. 1811 en György 2006: 149_ 150.

${ }^{11}$ Nrs. 1, 19, 22 en 53. 
István Hatvani was afkomstig uit Rimaszombat (nu: Řimavská Sobota in Slowakije). ${ }^{12} \mathrm{Na}$ studie in zijn geboorteplaats en enkele andere Hongaarse plaatsen, waaronder vanaf 1744 in Debrecen, studeerde ook hij in de jaren 1746-1748 in Zwitserland (Basel en Zürich) en in Nederland (Utrecht en Leiden). In Leiden studeerde hij bij Pieter van Musschenbroek (1692-1761), bij wie hij o.a. de elementaire beginselen van de elektriciteit onder de knie kreeg. Hatvani wees uitnodigingen van de universiteiten van Leiden en Heidelberg om daar te gaan werken af en keerde in 1749 terug naar Debrecen om daar vervolgens 37 jaar lang hoogleraar geometrie en filosofie te zijn. Hij was de eerste in Hongarije die, vanaf 1757, experimentele fysica onderwees. In 1776 schafte hij de electriseermachine aan die kort voordien was uitgevonden door Alessandro Volta. Hatvani volgde de natuurwetenschappelijke ontwikkelingen op de voet en deed als hoogleraar ook in het openbaar experimenten. Dit bezorgde hem de bijnaam 'Hongaarse doctor Faust'. Hatvani kocht in Leiden in 1748 een exemplaar van de Pharsalia-editie van Grotius die hij nadien aan de bibliotheek wijdde. ${ }^{13}$ Gezien de vele notities voorin en in het boek, had hij de tekst intensief bestudeerd.

De derde opperbibliothecaris over wie we hier moeten spreken, Miklos Sinai, ${ }^{14}$ afkomstig uit Hajdúbagos nabij Debrecen, ging na zijn studie in Debrecen in 17561758 op peregrinatio academica naar Wenen, Oxford, Franeker en Groningen. Na terugkomst in 1759 werd hij eerst dominee in Kunmadaras en was vervolgens vanaf 1760 in Debrecen hoogleraar geschiedenis en klassieke filologie. Hij behoorde tot de eersten die trachtten de geschiedenis van de Hongaarse protestantse kerk te boek te stellen. In 1791 werd hij na de dood van Szathmári Paksi István, over wie dadelijk meer, bijna met unanieme stemmen tot bisschop gekozen, maar zijn op basis van bestudering van de kerkgeschiedenis verkregen ideeën over de positie van leken in de kerk zorgden voor grote twisten en na 2 maanden werd hij gedwongen om af te treden als bisschop en professor. Hoewel de overheid tussenbeide kwam en de keizer hem na lange juridische procedures in 1800 in zijn functie van bisschop bevestigde, werd hij in 1803 definitief tot aftreden gedwongen. Men kende hem wegens jarenlange verdienste wel een pensioen toe. In de periode dat hij als hoogleraar in functie was, liet Sinai in 1775 een prachtig exemplaar van Leipziger editie door Kraus van de De jure belli ac pacis aankopen.

De genoemde opperbibliothecarissen waren allen eerder praktisch georiënteerde mannen. Echte theologen treffen we aan onder de bezitters van theologische Grotiana: István Paksi Szathmári (1719-1791), András Kaszoni (ca. 1740-

12 Gegevens op basis van Barcza 1988: 101-108, Zoványi 1977 nr. 1118 en György 2006: $150-151$.

13 Nr. 2 van de lijst.

${ }^{14}$ Gegevens op basis van Barcza 1988: 108-113, Zoványi 1977 nr. 2570 en Györi 2006: 151152. 
na 1771), ${ }^{15}$ Sámuel Hidi (ca. 1725-na 1771), ${ }^{16}$ János Récsei (1754-1835), István Toóth (ca. 1760-na 1808) ${ }^{17}$ en Sámuel Zilahy (ca. 1770-na 1804). ${ }^{18}$ Van hen zijn twee personen de interessantste. De eerste, István Paksi Szathmári ${ }^{19}$ werd geboren in Marosvásárhely (nu Tărgu Mureş in Roemenië) en vervolgde zijn studies in 1734 in Sárospatak. In de periode 1740-1745 was hij als student achtereenvolgens in Frankfurt an der Oder, Franeker, Leiden en Utrecht. Na terugkomst was hij van 1747 tot 1762 hoogleraar geschiedenis en klassieke filologie, vanaf 1760 hoogleraar theologie. Van 1785 tot zijn dood in 1791 was hij bisschop van de protestantse kerk in Debrecen (als voorganger van de hierboven genoemde Miklós Sinai). In de bibliotheek van Debrecen bevinden zich twee wat speciale Grotiana, een in 1763 geschonken Defensio fidei Catholicae, volgens vermelding door hem geschonken na terugkeer uit Utrecht, en een groot convoluut met werken van Georg Calixt (1586-1656) en enkele kleinere tractaten, waaronder een tractaatje tegen Johann Hülsemann (1602-1661). ${ }^{20}$ Calixtus was een tijdgenoot van Grotius en was evenals hij een irenist. Daarnaast was hij Lutheraan én syncretist, weshalve zijn geschriften onder de Lutheranen verbitterde reacties opriepen, onder welke die van Hülsemann.

Bij toeval is in de bibliotheek van Olomouc een groepje van 38 boeken bewaard gebleven dat rond 1750 door de douane in Olomouc in beslag werd geno-

15 Over András Kászoni is niet veel bekend. Hij schonk in 1768 nr. 39 aan de bibliotheek. Dit boek had hij zelf in 1766 overgenomen van István Dobolyi, dominee in Felsöbánya (nu Baia Sprie) die het ten geschenke had gekregen van Martinus B. Onodi. Kászoni kwam uit Kemecse, werd in 1759 in Debrecen ingeschreven en was in 1771 in Franeker. Gegevens op basis van Bozzay \& Ladányi 2007: 116 (nr. 1139), Szabadi 2013: 474 (nr. 7310) en Fockema Andreae 1978: 374 (nr. 13517).

16 Sámuel Hidi was afkomstig uit de regio Szatmár (nu Satu Mare) en werd in 1749 ingeschreven als student in Frankfurt an der Oder. Na terugkomst in Debrecen schonk hij in 1751 item nr. 51 aan de bibliotheek. Van 1751 tot 1771 was hij pastor in Monostorpályi, op ongeveer $25 \mathrm{~km}$ van Debrecen. Gegevens op basis van Lósy-Schmidt 1931: 318 en Tar 2004: 94 (nr. 489).

${ }^{17}$ István Toóth was afkomstig uit Mihályhát en werd in 1784 in Debrecen ingeschreven. Hij was in 1788 praeceptor oratoriae, in 1790 werd hij benoemd tot senior. Daarna ging hij op academische tour. In 1791-1792 was hij in Bern, waar hij blijkens zijn eigen notitie item nr. 46, een prachtig gebonden Annotationes in Vetus Testamentum kocht. Na studie in Erlangen in 1792 kwam hij terug in Debrecen en schonk in 1794 de delen II en III aan het College. Vervolgens was hij professor in Kecskemét, schonk in 1795 ook deel I aan het College. In 1799 was hij in Dunavecse om ten slotte te eindigen als superintendent en vicegeneraal notaris van de kerkprovincie Tiszántul. Gegevens op basis van Szögi 2001: 208 (nr. 3270), Szabadi 2013: 634 (nr. 10438), Hegyi \& Szögi 2016: 96 (nr. 647) en Fockema Andreae 1978: 340 (nr. 12299).

18 Sámuel Zilahy werd in 1790 te Debrecen ingeschreven als afkomstig uit Báránd. Zijn vader had ook in Debrecen gestudeerd. In 1784 was hij praeceptor paratistarum, in 1799 senior en in 1804 promoveerde hij tot doctor in de medicijnen. In 1794 schonk hij item nr. 34 (een verzamelband met o.a. De veritate religionis christianae) aan de bibliotheek. Gegevens op basis van Szabadi 2013: 735 (nr. 12453).

${ }^{19}$ Gegevens op basis van Barcza 1988: 98-99 en Zoványi 1977 nr. 2511.

${ }^{20} \mathrm{Nrs} .25$ en 54 
men bij een routinecontrole. ${ }^{21}$ De zending was bestemd voor István Paksi Szathmári. Opvallend aan het groepje was dat 17 ervan in het Nederlands waren en dat het geheel een goede keus uit Coccejaanse literatuur was. De zending was vermoedelijk op verzoek van Paksi Szathmári verstuurd door Ernst Willem Higt (1723-1762), rector van de Latijnse school in Alkmaar. Higt droeg aan zijn vriend zijn Nederlandse vertaling van toneelstukken van de Zwitserse theoloog Samuel Werenfels (1723-1762) uit 1746 op.

János Récsei was afkomstig uit het patriciaat van Debrecen en werd in 1769 op 15-jarige leeftijd bij het College ingeschreven. ${ }^{22} \mathrm{Na}$ zijn studie in Debrecen werd hij eerst rector in Érmihályfalva (nu Valea lui Mihai in Roemenië) om vervolgens geruime tijd in het buitenland door te brengen, o.a. was hij vanaf 1782 in Utrecht, waar hij in 1784 een Britse De veritate-editie kocht (nr. 30). Na terugkomst in Hongarije in 1787 was hij in verschillende Zevenburgse plaatsen pastor - in 1787 in Tiszaderzs, vanaf 1792 in Székelyhid (nu Săcueni in Roemenië) en na 1814 tot aan zijn dood in Érbogyoszló (nu Buduslău in Roemenië). Vanaf 1833 was hij afgevaardigde. Hij behoorde tot de grote weldoeners van het College: in 1821 schonk hij een groot bedrag om een leerstoel Hongaars in te richten, in 1829 schonk hij nog een bedrag voor het inrichten van een slaapzaal en tenslotte vermaakte hij zijn complete bezit aan het College om de leerstoel Hongaars te onderhouden. Zijn De veritate-exemplaar was een van de 864 boeken die hij aan het College naliet.

\section{Wat vertellen de Grotiana?}

Uit de voorkeuren van de bezitters is duidelijk dat het werk van Grotius als jurist en filoloog internationaal zeer werd gewaardeerd, tamelijk onafhankelijk van de theologische of ideologische richting. Zowel in Praag en Olomouc, als ook in Debrecen komt echte interesse in zijn theologisch werk vooral in de tweede helft van de achttiende eeuw op, dus in de periode dat de Verlichting haar hoogtij vierde. In Debrecen behoorden de bezitters tot de verlichte theologen die probeerden om al dan niet met succes het College te hervormen. In Olomouc en Praag zijn Grotiana juist meestal afkomstig uit collecties van buiten de universiteit, namelijk uit opgeheven kloosters geleid door verlichte abten of uit adellijke schenkingen van de negentiende eeuw.

Zoals de jezuïeten zich vooral in Olomouc actief tegen 'nieuwlichterij' verweerden, zo gold dit ook voor de hogere protestantse clerus in Debrecen, waarbij de modernisering van ideeën in Debrecen vooral van het College uitging en

21 Zie Engelbrecht 2015: 202-203, 207.

22 Gegevens op basis van Barcza 1988: 83, 437, Szabadi 2013: 522 (nr. 8315) en Zoványi 1977 nr. 2346. 
deze moderne ideeën veelal tijdens studie in Nederland en Zwitserland werden opgedaan. Het werk van Hugo de Groot vormt zo een soort 'lakmoesproef' voor verlichte ideeën.

\section{Bibliografie}

Barcza, József (ed.) (1988): A Debreceni Református Kollégium Története. Budapest: Kiadja a Magyarországi Református Egyház Zsinati Irodájának Sajtóosztálya. Laatst geraadpleegd op 8.04.2017 (digit.drk.hu/?m=lib\&book=2\&view=pdf).

Bozzay, Reka \& Ladányi, Sándor (2007): Magyarországi diákok holland egyetemeken 1595-1918 / Hongaarse studenten aan Nederlandse universiteiten 1595-1918. Budapest: Eötvös Loránd Tudományegyetem Levéltára.

Bozzay, Reka (2017): "Nederlandse universiteiten en het Hongaarse protestantisme in de vroegmoderne tijd". In: Hamers, Bas \& Waterlot, Muriel (ed.): De Lage Landen en de religie. De positie van de religie in verschillende culturele aspecten. Lublin: Wydawnictwo KUL (in druk).

Črnejová, Ivana (2001): "The administrative and institutional development of Prague University 1622-1802”. In: Kavka, František \& Petráň, Josef(ed.): A History of Charles University. Vol. 1. 1348-1802. Praha: Karolinum, 261-297.

Engelbrecht, Wilken (2015): "De lotgevallen van een groepje 'ketterse' boeken uit de Lage Landen". In: Engelbrechtová, Jana (ed.): De Nederlandstalige literatuur internationaal. Centraal-Europa en de Lage Landen. Olomouc: Univerzita Palackého, 189-213.

Engelbrechtová, Jana (1999/2000): "Grotiana in the Czech Republic". In: Grotiana. New Series 20/21: 107-120.

Engelbrechtová, Jana (2001): "Hugo de Groot en diens tractaat De veritate religionis christianae". In: Neerlandica Wratislaviensia 13: 25-38.

Engelbrechtová, Jana (2017): "Changing conservative thinking in a Jesuit University. The reception of Grotius in Olomouc". In: Grotiana. New Series 38 (in druk).

Eyffinger, Arthur C. (1983): The Grotius Collection at the Peace Palace. A Concise Catalogue. Assen: Van Gorcum.

Fockema, Andreae S.J. \& Meijer, Theodorus J. (1978): Album studiosorum Academiae Franekerensis (1585-1811, 1816-1844). Franeker: T. Wever.

Glonek, Jiř́ (2016a): “Jan Nepomuk Alois Hanke z Hankenštejna a role Lycejní knihovny v Olomouci při rušení klášterních knihoven na Moravě a ve Slezsku”. In: Korhoň, Miloš \& Vintrová, Tereza (ed.): Chrám věd a múz. Dějiny Vědecké knihovny v Olomouci. Olomouc: Vědecká knihovna v Olomouci, 76-99.

Glonek, Jiř́ (2016b): “Zrození veřejné knihovny a její neklidné počátky (1773-1791)”. In: Korhoň, Miloš \& Vintrová, Tereza (ed.): Chrám věd a múz. Dějiny Vědecké knihovny v Olomouci. Olomouc: Vědecká knihovna v Olomouci 2016, 49-75.

Györi, János (2006): "Egész Magyarországnak és Erdélységnek világositó lámpása". A Debreceni Református Kollégium törtenete. Debrecen: Kiadta a Tiszántúli Református Egyházkerület.

Györi, János (2013): "Debrecen, das 'Calvinistische Rom'”. In: Balcke, Joachim, Rohdewald, Stefan \& Wünsch, Thomas (ed.): Religiöse Erinnerungsorte in Ostmitteleuropa. Konstitution und Konkurrenz im nationen- und epochenübergreifenden Zugriff. Berlin: Akademie-Verlag, $166-173$.

Hegyi, Ádám \& Szögi, László (2016): Magyarországi diákok svájci egyetemeken és föiskolákon 1526-1919 / Ungarländische Studenten an schweizerischen Universitäten und Hochschulen 1526-1919. Budapest: Eötvös Loránd Tudományegyetem Levéltára. 
Huber, Kurt Augustinus (2005): Katholische Kirche und Kultur in Böhmen. Münster: Lit.

Index librorum prohibitorum Sanctissimi Domini Nostri Benedicti XIV, Pontificis Maximi iussu recognitus, atque editus, Romae: Ex Typographia Rev. Camerae Apostolicae 1758.

Kiedroń, Stefan (2015): "Cultural influence of the low countries through old prints". In: Engelbrechtová, Jana (ed.): Dutch - Flemish - Central European Relations. Olomouc: Palacký University in Olomouc, 24-40.

Kiedroń, Stefan, Engelbrecht, Wilken \& Hrnčírová, Zdenka (ed.) (2010): Nederlandse oude drukken in Bohemen, Moravië en Silezië (1500-1800) / Netherlandish Old Prints in Bohemia, Moravia and Silesia (1500-1800). Wrocław: Atut.

Lósy-Schmidt, Ede (1931): Hatvani István élete és művei 1718-1786. I. Hatvani István élete és önéletrajza. Az ördöngösségéröl szárnyrakelt mondák. Debrecen: Studium Könyvkiadó R.T.

Meulen, Jacob Ter \& Diermanse, Pieter J.J. (1995): Bibliographie des écrits imprimés de Hugo Grotius. Zutphen: De Jongh (oorspronkelijke uitgave: La Haye: Martinus Nijhoff, 1950).

Osler, Douglas J. (2016): “The restless Mind and the Living Text. The First Edition of Grotius' De iure belli ac pacis". Grotiana 37, 2: 1-15.

Strelka, Joseph (1990): “On German Geistesgeschichte and its impact on comparative literature”. In: Jost, François \& Friedman, Melvin J. (ed.): Aesthetics and the Literature of Ideas: Essays in Honor of A. Owen Alridge. Newark: University of Delaware Press, 44-52.

Szabadi, István (ed.) (2013): Intézménytörténeti források a Debreceni Református Kollégium Levéltárában I-II. Debrecen: Tiszántúli Református Egyházkerület.

Szögi, László (2001): Magyarországi diákok németországi egyetemeken és föiskolákon 1789-1919 / Ungarländische Studenten an den deutschen Universitäten und Hochschulen 1789-1919. Budapest: Eötvös Loránd Tudományegyetem Levéltára.

Tar, Attila (2004): Magyarországi diákok németországi egyetemeken és föiskolákon 1694-1789 / Ungarländische Studenten an den deutschen Universitäten und Hochschulen 1694-1789. Budapest: Eötvös Loránd Tudományegyetem Levéltára.

Zoványi, Jenö (1977): Magyarországi protestans egyháztörténeti lexikon. Budapest: Kiadja a Magyarországi Református Egyház Zsinati Irodájának Sajtóosztálya ( $3^{\mathrm{e}}$ druk). Laatst geraadpleegd op 8.04.2017 (http://digit.drk.hu/?m=lib\&c=7\&book=3).

\section{Geraadpleegde websites}

http://silver.drk.hu/en/content/special-collections - webpagina met gegevens over de speciale collecties van de Grote Bibliotheek te Debrecen (laatst geraadpleegd op 1.04.2017).

http://www.nkp.cz/sbirky/podle-typu-dokumentu/rukopisy-inkunabule-a-stare-tisky/fond - webpagina met gegevens over de afdeling oude drukken van de Nationale Bibliotheek te Praag (laatst geraadpleegd op 1.04.2017).

http://www.vkol.cz/cs/historicke-fondy/ - webpagina met gegevens over de historische afdeling van de Wetenschappelijke Bibliotheek te Olomouc (laatst geraadpleegd op 1.04.2017). 


\begin{tabular}{|c|c|c|c|c|c|c|c|c|}
\hline 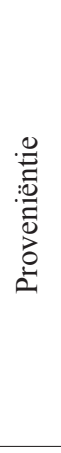 & 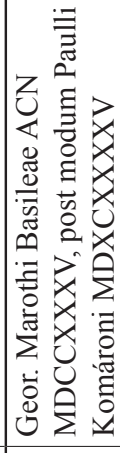 & 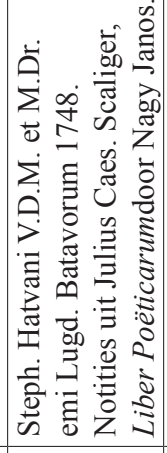 & 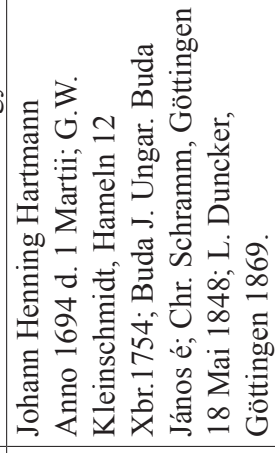 & & 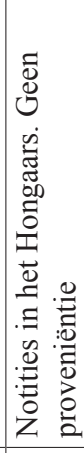 & $\mid$ & 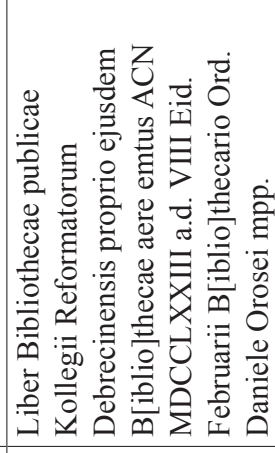 & 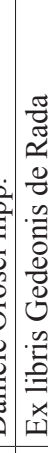 \\
\hline 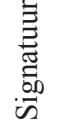 & 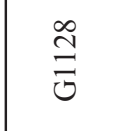 & 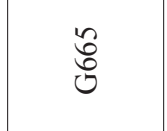 & 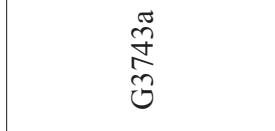 & $\begin{array}{l}\text { \& } \\
\text { o }\end{array}$ & $\begin{array}{l}0 \\
\infty \\
0 \\
0\end{array}$ & $\stackrel{?}{\Sigma}$ & $\stackrel{\Sigma}{\Sigma}$ & $\Sigma$ \\
\hline$\sum_{i=1}^{O}$ & $\hat{\sim}$ & $\underset{ঙ}{\stackrel{丶}{\forall}}$ & 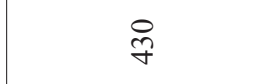 & oे & $\frac{n}{n}$ & $\hat{\circ}$ & ๙ู & in \\
\hline 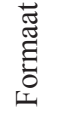 & $\stackrel{\infty}{\infty}$ & $\stackrel{\circ}{\beth}$ & $\stackrel{\circ}{\beth}$ & $\stackrel{\infty}{\infty}$ & $\stackrel{\circ}{\simeq}$ & io & $\stackrel{\infty}{\infty}$ & $\infty$ \\
\hline 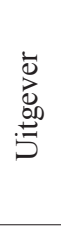 & 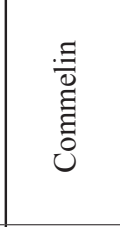 & $\frac{3}{\frac{\pi}{0}}$ & $\frac{3}{\frac{\pi}{0}}$ & 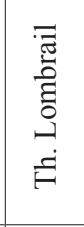 & 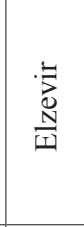 & 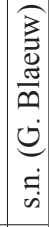 & 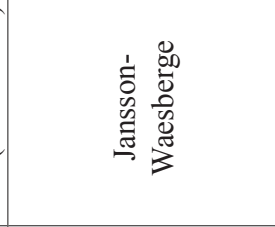 & $\mid \begin{array}{l}\frac{1}{0} \\
\frac{0}{5} \\
\frac{0}{0} \\
3\end{array}$ \\
\hline$\frac{\tilde{\tilde{E}}}{\frac{\pi}{2}}$ & $\begin{array}{l}\frac{0}{0} \\
\frac{0}{0} \\
\frac{0}{0} \\
\frac{0}{1}\end{array}$ & 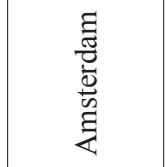 & 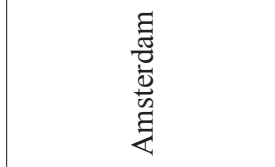 & 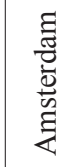 & 总 & 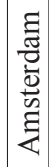 & 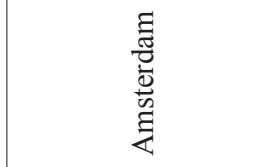 & 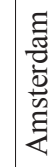 \\
\hline 点 & $\overbrace{0}^{0}$ & $\underset{d}{\tilde{O}}$ & $\underset{d}{\tilde{d}}$ & 음 & 웅 & $\overline{6}$ & $\stackrel{ }{2}$ & $\stackrel{\overbrace{}}{\varrho}$ \\
\hline 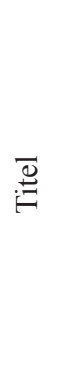 & 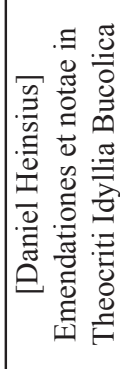 & 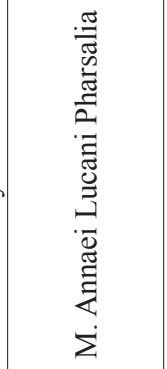 & 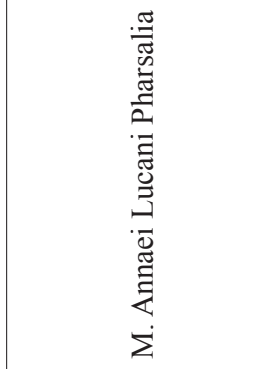 & 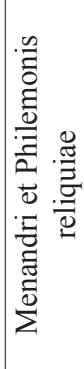 & 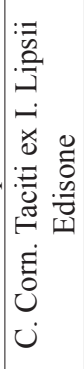 & 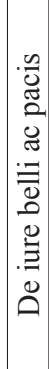 & 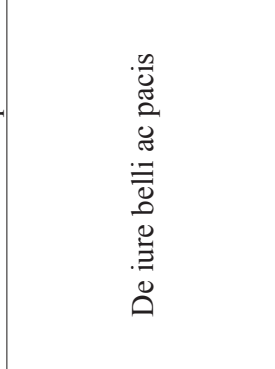 & 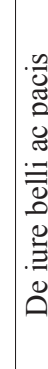 \\
\hline$\stackrel{0}{z}$ & $\dot{-}$ & ن & $\dot{m}$ & $\dot{\nabla}$ & $\dot{r}$ & $0^{\circ}$ & $r$ & $\infty$ \\
\hline
\end{tabular}




\begin{tabular}{|c|c|c|c|c|c|c|}
\hline 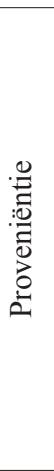 & 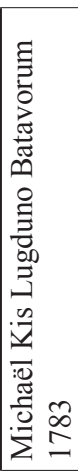 & 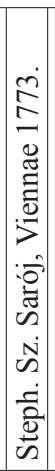 & 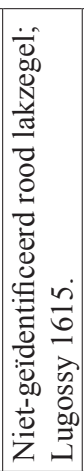 & 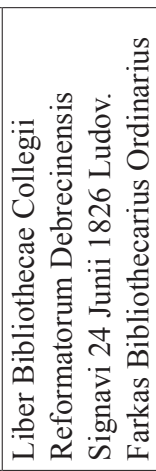 & 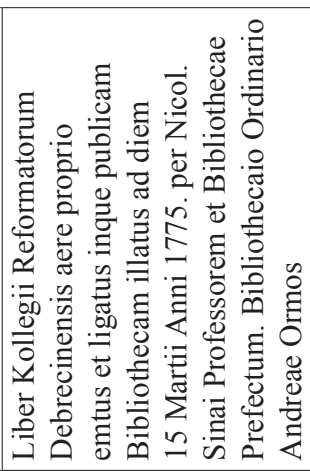 & 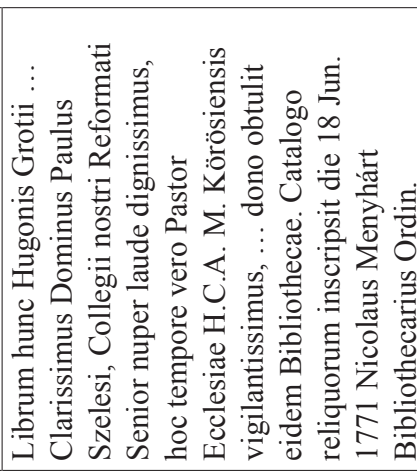 \\
\hline 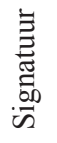 & $\begin{array}{l}\overrightarrow{\widetilde{d}} \\
\stackrel{\Sigma}{\Sigma}\end{array}$ & 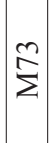 & $\stackrel{ \pm}{\Sigma}$ & $\frac{1}{2}$ & $\stackrel{N}{\Sigma}$ & $\frac{\infty}{\Sigma}$ \\
\hline$\sum_{i}$ & ชิ & d & है & $\stackrel{\infty}{8}$ & $\frac{0}{6}$ & $\sqrt{6}$ \\
\hline 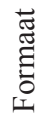 & $\stackrel{\infty}{\infty}$ & $\infty$ & $\stackrel{\infty}{\infty}$ & $\stackrel{\circ}{+}$ & $\stackrel{\infty}{\infty}$ & $\stackrel{\circ}{+}$ \\
\hline 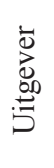 & 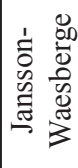 & 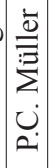 & 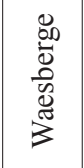 & $\begin{array}{l}\overrightarrow{0} \\
\vec{z} \\
\vdots \\
0 \\
0\end{array}$ & 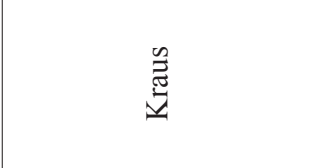 & $\dot{4}$ \\
\hline$\frac{\bar{\pi}}{\frac{\pi}{2}}$ & 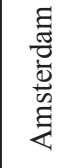 & 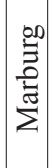 & 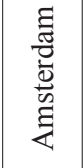 & 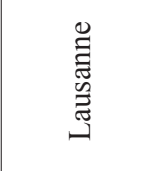 & 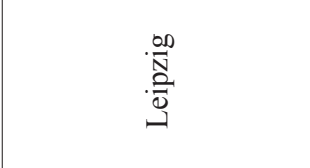 & 苞 \\
\hline 胥 & $\stackrel{\mathbb{N}}{\text { I }}$ & $\stackrel{ \pm}{\stackrel{\Xi}{\Xi}}$ & $\stackrel{n}{N}$ & 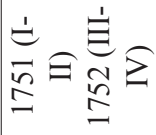 & $\stackrel{\infty}{\stackrel{\infty}{n}}$ & ิㅡㅁ \\
\hline 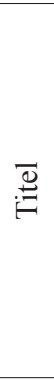 & $\begin{array}{l}\frac{n}{0} \\
0 \\
0 \\
0 \\
0 \\
. \\
\overline{0} \\
0 \\
0 \\
0 \\
. \\
0 \\
0\end{array}$ & 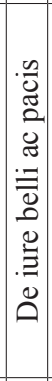 & 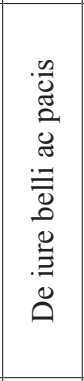 & 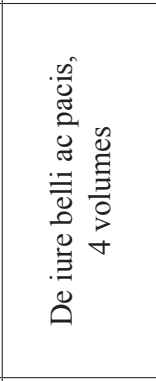 & 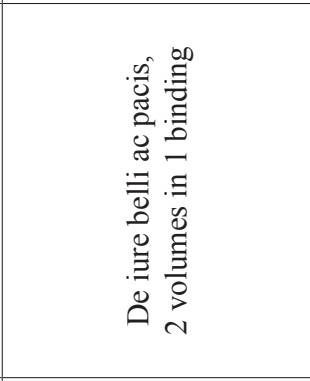 & 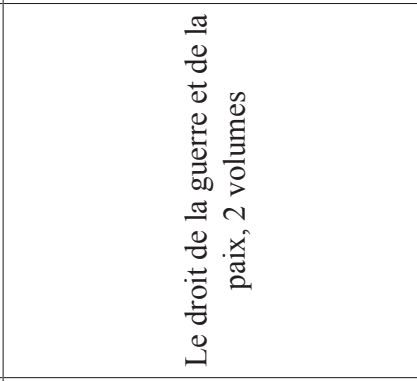 \\
\hline$\dot{z}$ & $\sigma^{\circ}$ & 0 & $\dot{\Xi}$ & $\stackrel{\sim}{ }$ & $\ddot{\sim}$ & 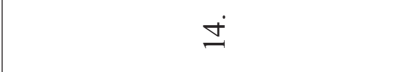 \\
\hline
\end{tabular}




\begin{tabular}{|c|c|c|c|}
\hline 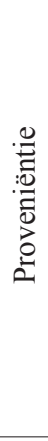 & & 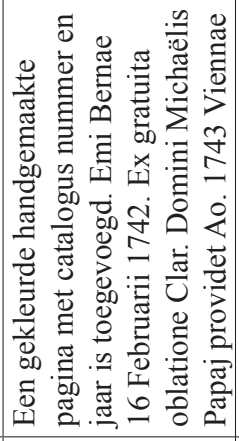 & 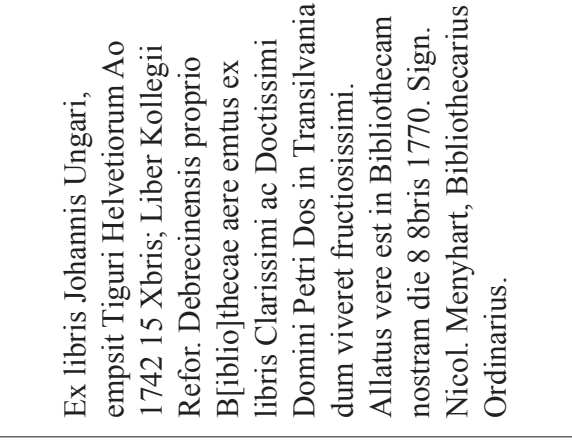 \\
\hline 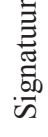 & $\stackrel{\curvearrowright}{\stackrel{\Omega}{\Sigma}}$ & 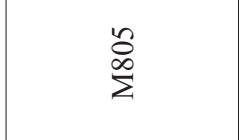 & $\underset{\nabla}{\vec{Z}}$ \\
\hline$\sum_{i}$ & రై & $\stackrel{\circ}{z} \sum_{i}$ & సે \\
\hline 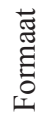 & $\stackrel{\circ}{\forall}$ & $\stackrel{\circ}{\beth}$ & $\stackrel{\infty}{\infty}$ \\
\hline 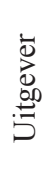 & 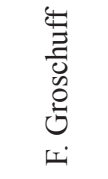 & 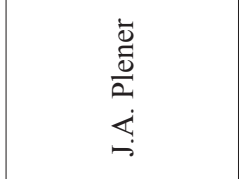 & 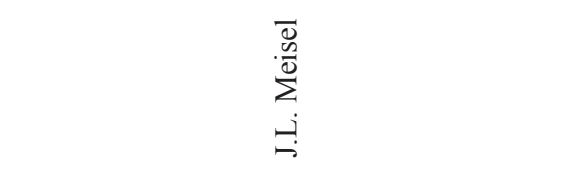 \\
\hline$\frac{\tilde{a}}{\frac{\pi}{\pi}}$ & 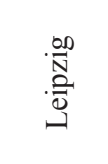 & 志 & 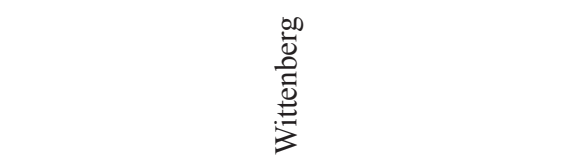 \\
\hline 点 & $\stackrel{\hat{\imath}}{ }$ & 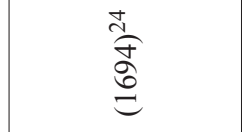 & $\stackrel{\Delta}{I}$ \\
\hline 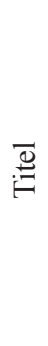 & 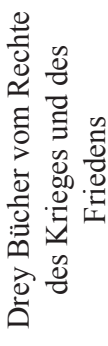 & 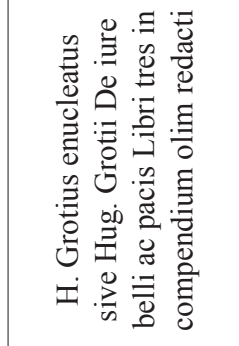 & 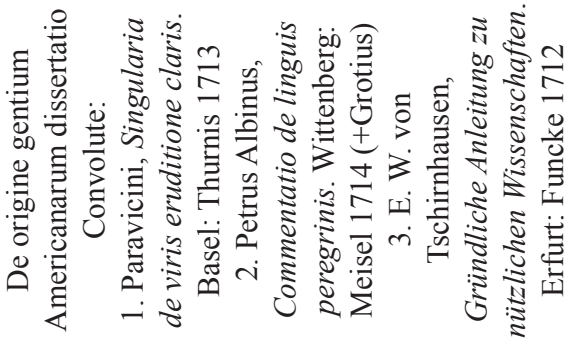 \\
\hline$\stackrel{0}{z}$ & $\stackrel{n}{n}$ & $\stackrel{-}{\circ}$ & I \\
\hline
\end{tabular}

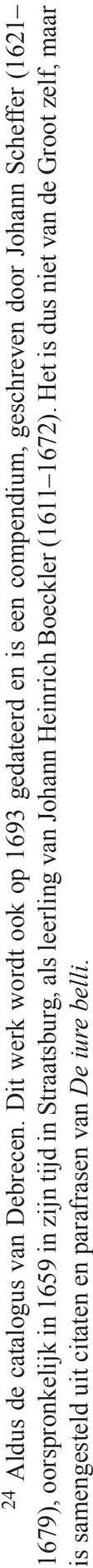




\begin{tabular}{|c|c|c|c|}
\hline 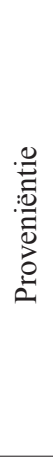 & 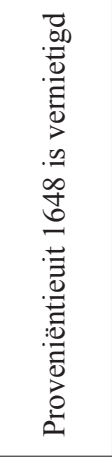 & 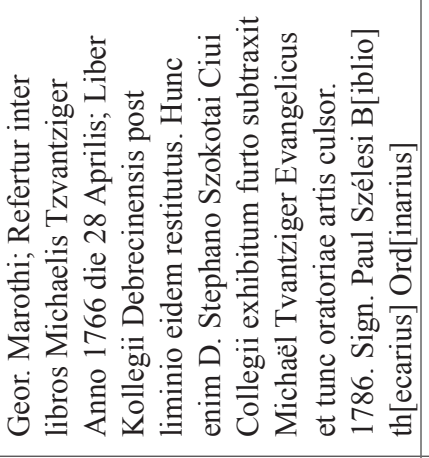 & 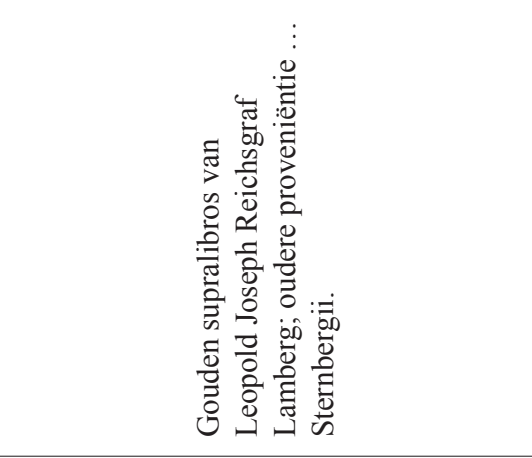 \\
\hline 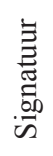 & શે & $\begin{array}{l}\widetilde{a} \\
\mathscr{0} \\
\mathscr{u}\end{array}$ & 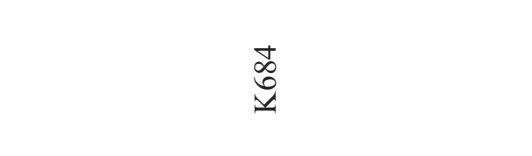 \\
\hline$\sum_{i}$ & $\stackrel{n}{\approx}$ & $\vec{I}$ & ‡ \\
\hline 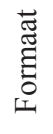 & $\infty$ & $\stackrel{\circ}{\beth}$ & $\stackrel{\circ}{\beth}$ \\
\hline $\begin{array}{l}\overrightarrow{0} \\
\vec{\Delta} \\
\overrightarrow{0} \\
\overrightarrow{5}\end{array}$ & $\begin{array}{l}\overrightarrow{7} \\
\stackrel{N}{N} \\
\text { III }\end{array}$ & 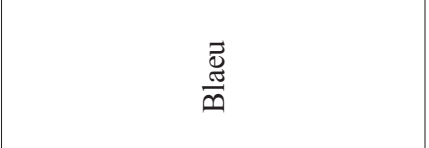 & $\frac{\vec{\Xi}}{\ddot{m}}$ \\
\hline $\begin{array}{l}\frac{\tilde{\mathbb{E}}}{\tilde{N}} \\
\frac{\mathbb{E}}{2}\end{array}$ & 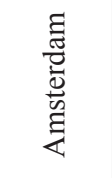 & 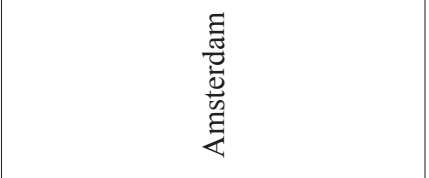 & 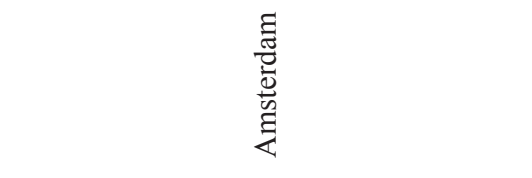 \\
\hline 志 & బ్ & : & $\begin{array}{l}\infty \\
: \\
b \\
0\end{array}$ \\
\hline$\stackrel{\bar{\Xi}}{\stackrel{\Xi}{\models}}$ & 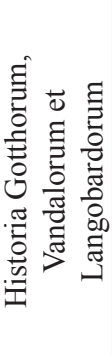 & 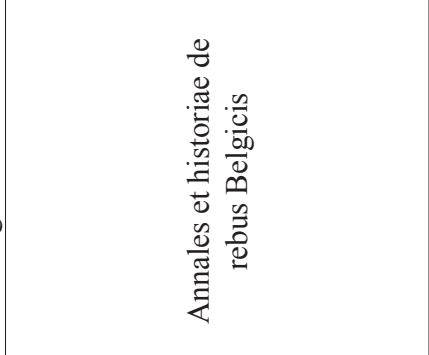 & 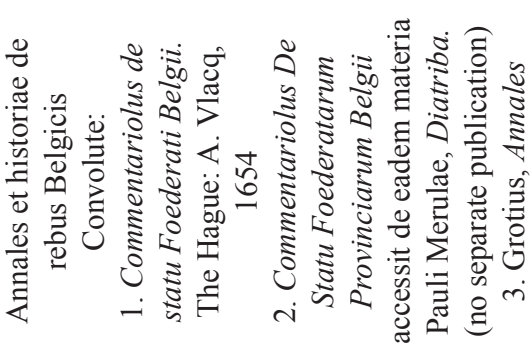 \\
\hline$\stackrel{\circ}{z}$ & $\stackrel{\infty}{\rightarrow}$ & $\stackrel{2}{2}$ & $\dot{\sim}$ \\
\hline
\end{tabular}




\begin{tabular}{|c|c|c|c|c|c|c|c|c|c|}
\hline 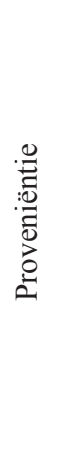 & 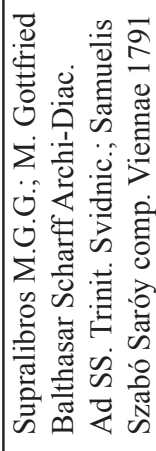 & 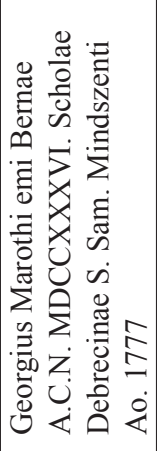 & 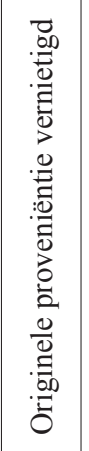 & & 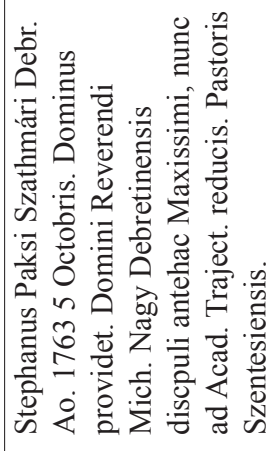 & 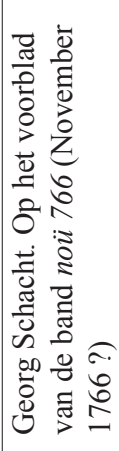 & 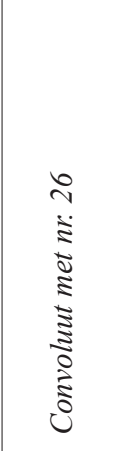 & 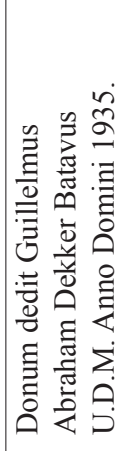 & \\
\hline 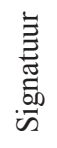 & $\frac{\partial}{\vec{v}}$ & $\frac{\bar{D}}{\sum^{\infty}}$ & \begin{tabular}{l} 
?q \\
\multirow{0}{0}{}
\end{tabular} & $\begin{array}{l}\text { वे } \\
\dot{\Sigma}\end{array}$ & 菅 & $\overrightarrow{\vec{J}}$ & 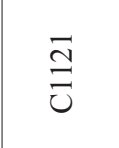 & $\begin{array}{l}\widetilde{\Omega} \\
\tilde{U}\end{array}$ & $\stackrel{\hat{0}}{0}$ \\
\hline$\sum_{i}$ & I & $\stackrel{\curvearrowright}{\curvearrowright}$ & $\begin{array}{l}\Phi_{\infty} \\
\end{array}$ & $\stackrel{\infty}{\infty}$ & $\stackrel{\infty}{\sim}$ & నू & $\begin{array}{l}\frac{N}{N} \\
\kappa\end{array}$ & ू̆ & $\begin{array}{l}\infty \\
\stackrel{2}{\circ}\end{array}$ \\
\hline 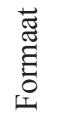 & $\stackrel{\circ}{+}$ & $\stackrel{\Xi}{\Xi}$ & $\infty$ & $\stackrel{\circ}{\beth}$ & $\stackrel{\circ}{\Xi}$ & $\stackrel{\Xi}{\beth}$ & $\stackrel{\circ}{\beth}$ & 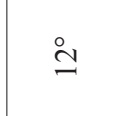 & $\infty$ \\
\hline 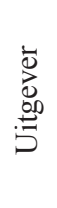 & $\begin{array}{l}\frac{\bar{\Xi}}{\tilde{m}} \\
\frac{\pi}{m}\end{array}$ & 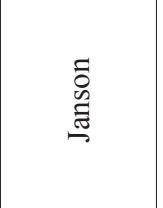 & $\begin{array}{l}\overrightarrow{0} \\
\stackrel{0}{0}\end{array}$ & 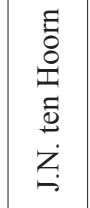 & 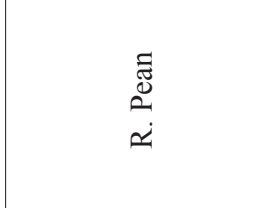 & 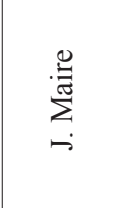 & 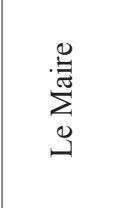 & $\begin{array}{l}\vec{D} \\
\text { D } \\
\frac{N}{\mid I}\end{array}$ & 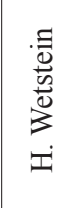 \\
\hline $\begin{array}{l}\frac{n}{\mathbb{J}} \\
\frac{\pi}{\alpha}\end{array}$ & 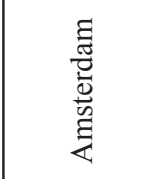 & 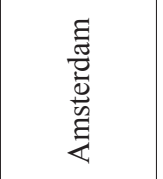 & 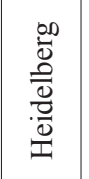 & 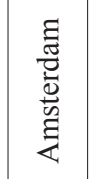 & 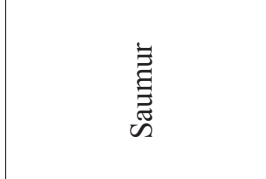 & 苛 & 苞 & 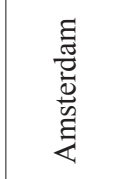 & 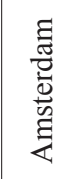 \\
\hline 壳 & ह̂ & ?్ֶd & స్ర్రి & 芯 & 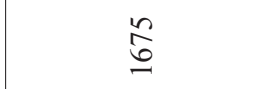 & 㲾 & 吕 & త్ర & هి \\
\hline 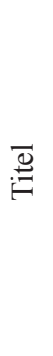 & 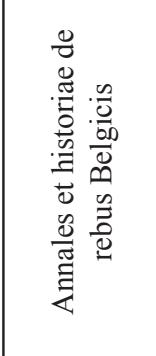 & 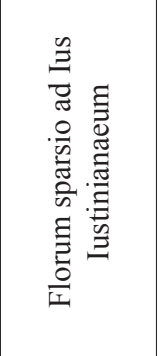 & 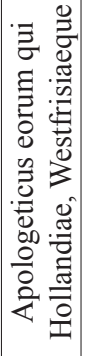 & 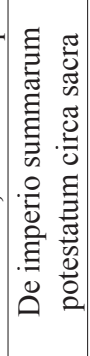 & 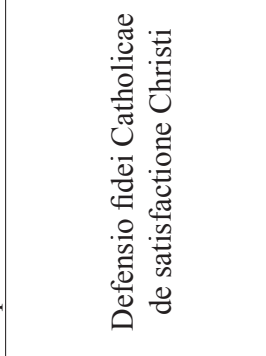 & 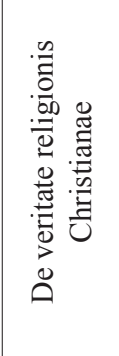 & 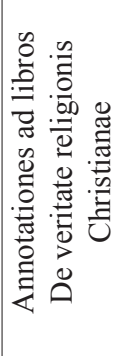 & 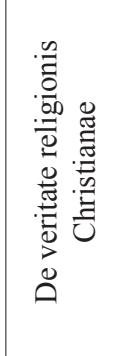 & 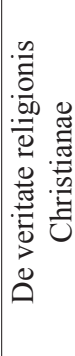 \\
\hline$\stackrel{2}{z}$ & $\dot{\vec{\lambda}}$ & ป் & $\dot{\vec{\lambda}}$ & $\dot{J}$ & $\ddot{\imath}$ & $\dot{\sim}$ & $\dot{\sim}$ & $\stackrel{\dot{\sim}}{\sim}$ & $\dot{i}$ \\
\hline
\end{tabular}




\begin{tabular}{|c|c|c|c|c|c|c|c|}
\hline 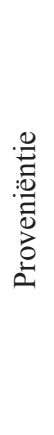 & 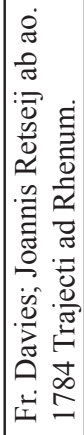 & 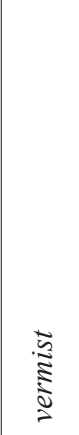 & & 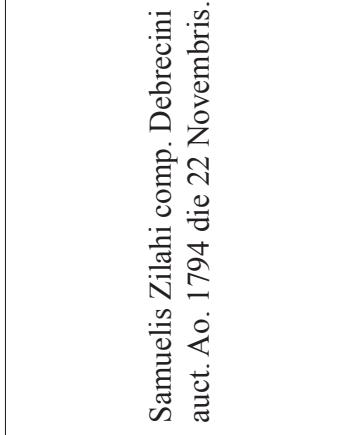 & 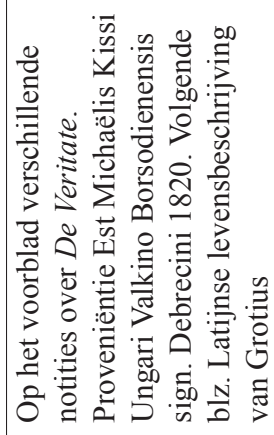 & 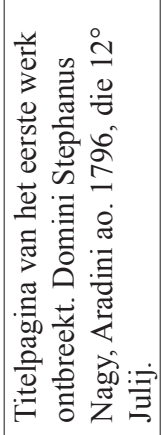 & \\
\hline 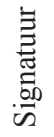 & 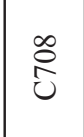 & $\stackrel{\stackrel{尺}{0}}{\text { to }}$ & 药 & 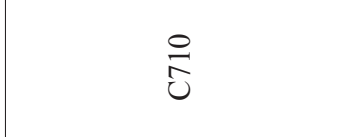 & $\frac{a}{\vec{v}}$ & $\begin{array}{l}i \bar{n} \\
\tilde{0} \\
0\end{array}$ & 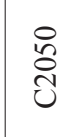 \\
\hline$\sum_{i}$ & ڤे & $\frac{2}{a}$ & ลิ & $\stackrel{m}{\hat{\sigma}}$ & $\frac{n}{a}$ & $\frac{n}{a}$ & $\frac{n}{\frac{n}{n}}$ \\
\hline 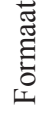 & $\stackrel{\circ}{\infty}$ & $\stackrel{\infty}{\infty}$ & $\stackrel{\infty}{\infty}$ & $\stackrel{\circ}{\infty}$ & $\stackrel{\circ}{\infty}$ & $\stackrel{\infty}{\infty}$ & $\stackrel{\infty}{\infty}$ \\
\hline 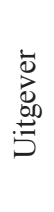 & 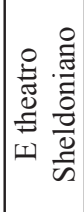 & 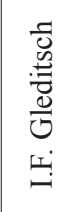 & 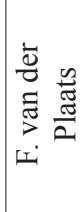 & 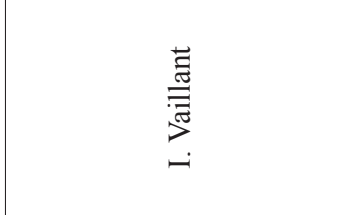 & 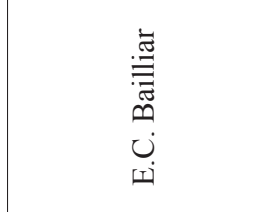 & 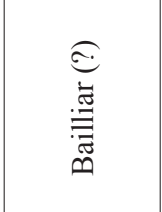 & 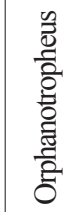 \\
\hline$\frac{\frac{\tilde{J}}{\tilde{G}}}{2}$ & 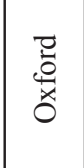 & 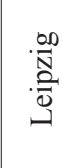 & 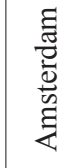 & 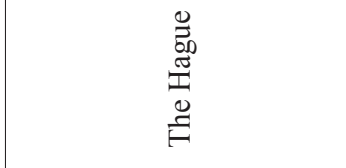 & 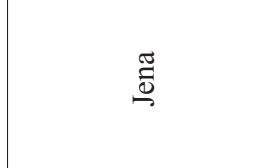 & 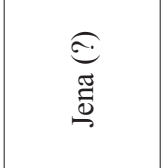 & 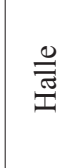 \\
\hline 胥 & $\stackrel{8}{\circledR}$ & $\stackrel{尺}{I}$ & $\stackrel{\text { ㅇ }}{ }$ & $\stackrel{\infty}{I}$ & $\stackrel{\text { N }}{\text { I }}$ & $\begin{array}{l}\widehat{\underbrace{}} \\
\stackrel{0}{0} \\
\end{array}$ & હે \\
\hline$\underset{\Xi}{\stackrel{\Xi}{\Xi}}$ & 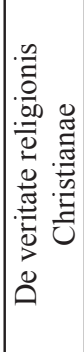 & 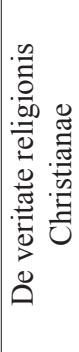 & 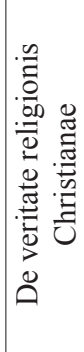 & 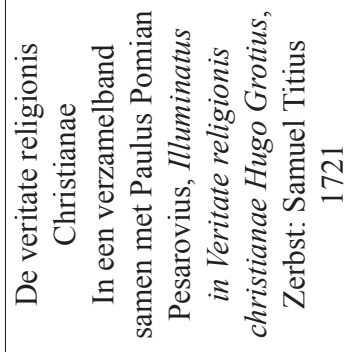 & 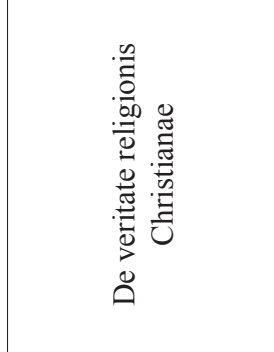 & 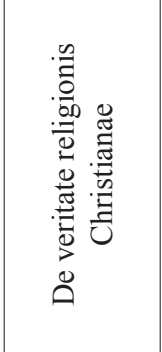 & 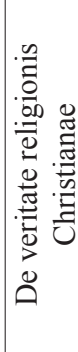 \\
\hline$\dot{z}$ & లి & $\bar{m}$ & ñ & 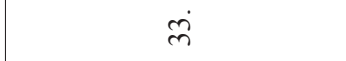 & m & $\stackrel{m}{n}$ & $\dot{n}$ \\
\hline
\end{tabular}




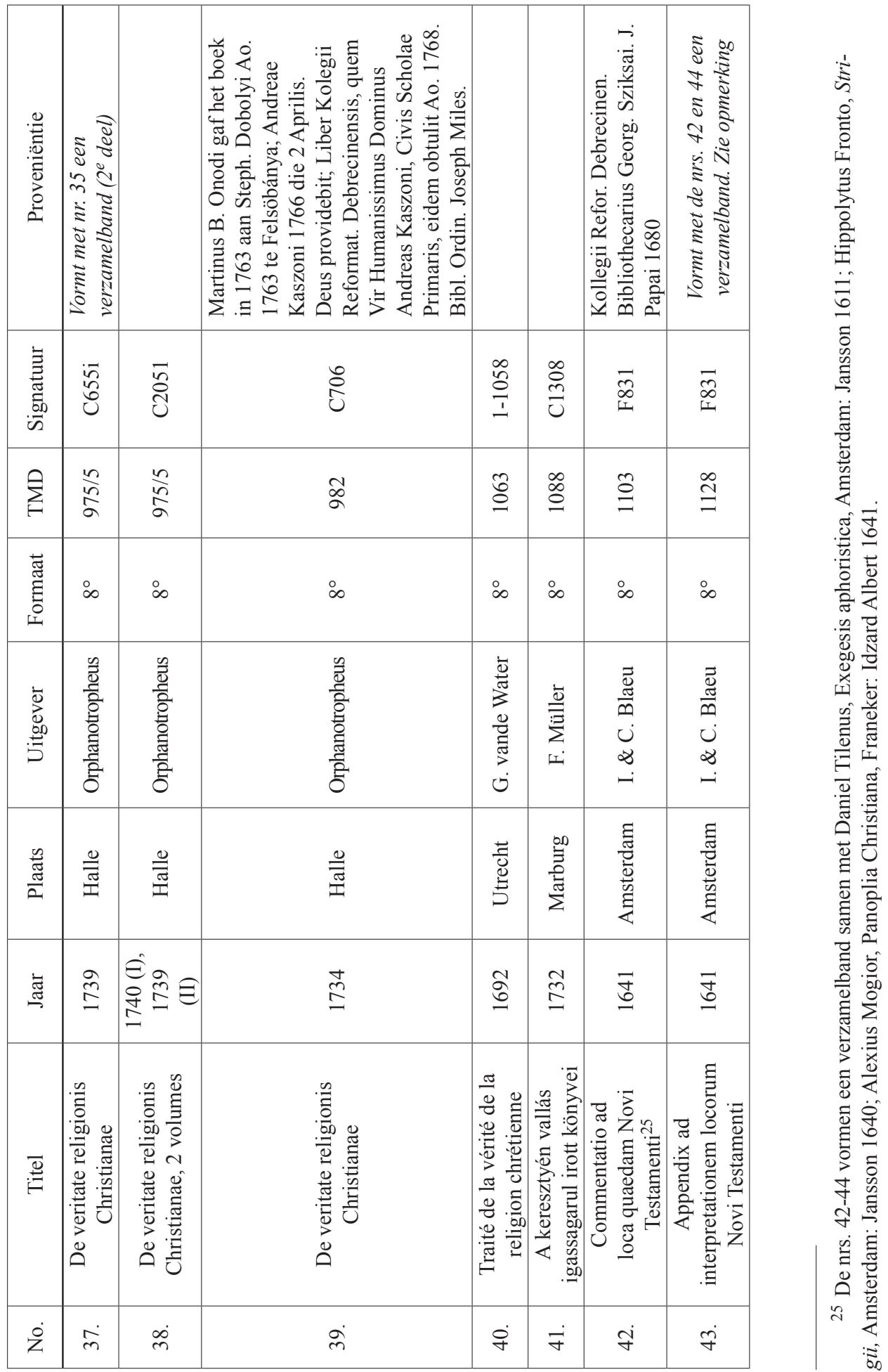




\begin{tabular}{|c|c|c|c|}
\hline 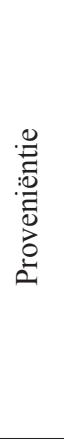 & 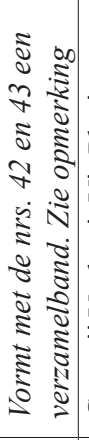 & 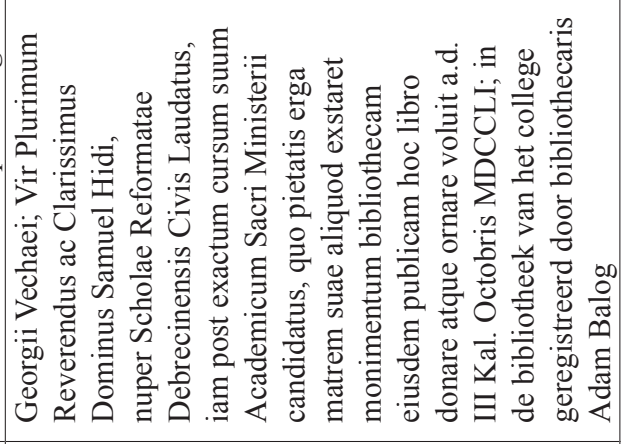 & 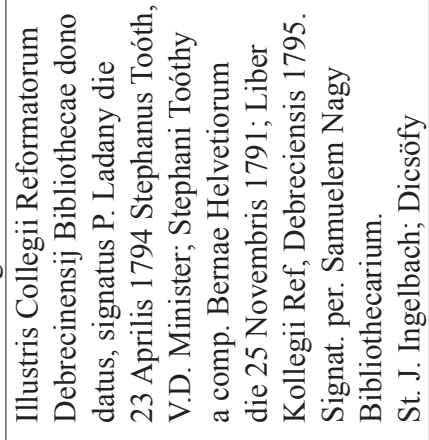 \\
\hline 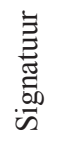 & $\begin{array}{l}\vec{\infty} \\
\stackrel{\infty}{1}\end{array}$ & $\begin{array}{l}0 \\
\infty \\
\text { d }\end{array}$ & 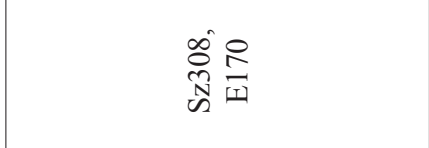 \\
\hline$\sum_{i}$ & $\stackrel{\stackrel{+}{\infty}}{\stackrel{\infty}{\Xi}}$ & $\stackrel{\hat{m}}{=}$ & $\stackrel{n}{=}$ \\
\hline 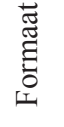 & $\therefore$ & 宁 & $\stackrel{\circ}{*}$ \\
\hline 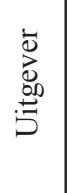 & 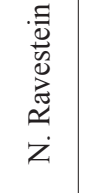 & 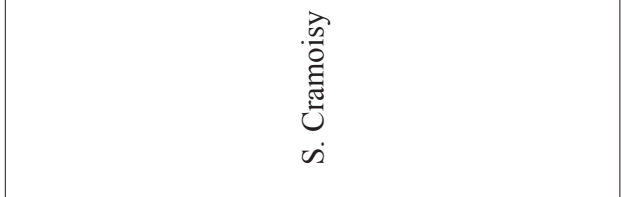 & 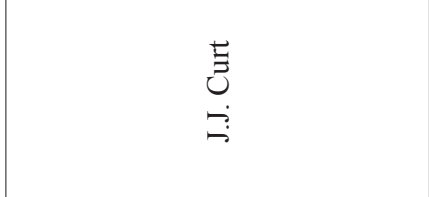 \\
\hline$\frac{\mathbb{E}^{\frac{\pi}{2}}}{2}$ & 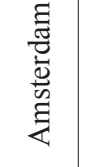 & 垉 & 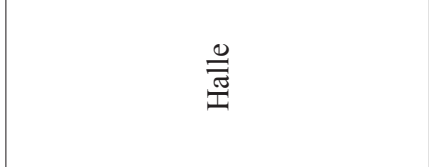 \\
\hline 点 & ฮิ & $\underset{-}{f}$ & 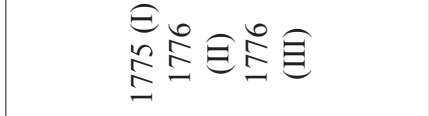 \\
\hline 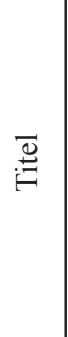 & 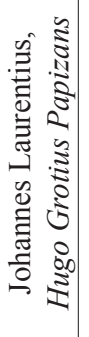 & 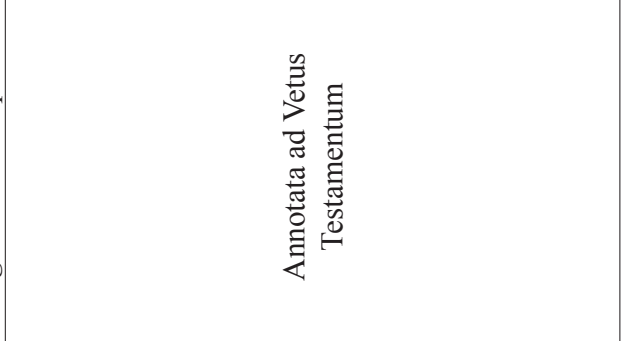 & 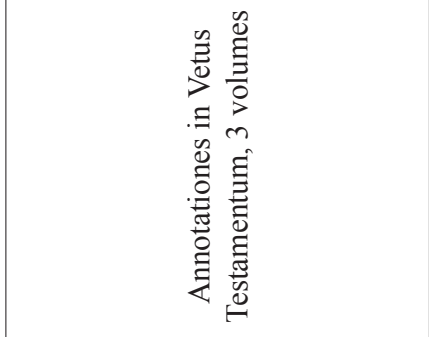 \\
\hline$\dot{z}$ & F & 'f & $\dot{f}$ \\
\hline
\end{tabular}




\begin{tabular}{|c|c|c|c|c|c|c|c|}
\hline 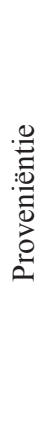 & 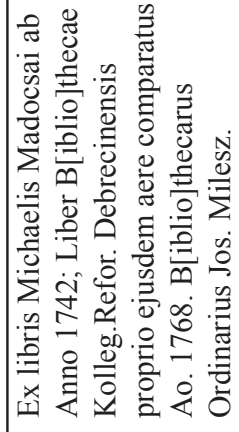 & 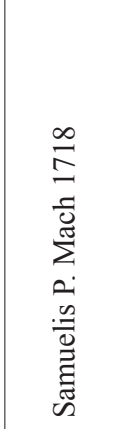 & 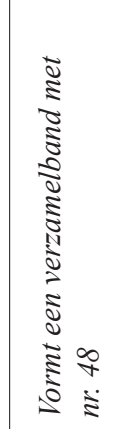 & 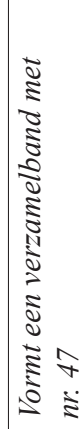 & 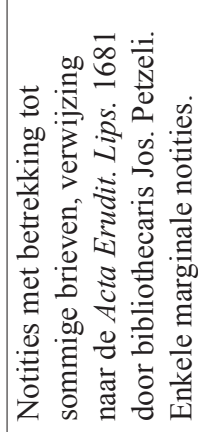 & & 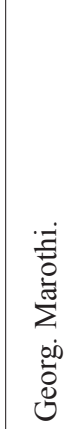 \\
\hline 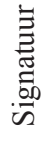 & 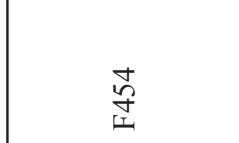 & $\stackrel{n}{0}$ & $\begin{array}{l}n \\
0 \\
0\end{array}$ & $\stackrel{\stackrel{+}{7}}{\stackrel{+}{ \pm}}$ & $\stackrel{2}{2}$ & 令 & 号 \\
\hline$\sum_{i}$ & $\stackrel{N}{\Xi}$ & $\stackrel{\infty}{=}$ & 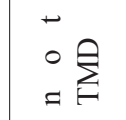 & $\stackrel{\infty}{=}$ & 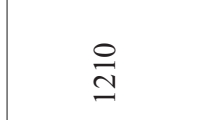 & $\stackrel{m}{I}$ & $\stackrel{\infty}{\stackrel{(}{\beth}}$ \\
\hline 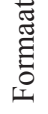 & $\stackrel{\circ}{\beth}$ & $\stackrel{\infty}{\infty}$ & $\stackrel{\infty}{\infty}$ & $\stackrel{\circ}{\simeq}$ & $\stackrel{\circ}{+}$ & $\stackrel{\stackrel{\circ}{I}}{ }$ & $\stackrel{\circ}{\sim}$ \\
\hline 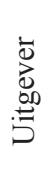 & 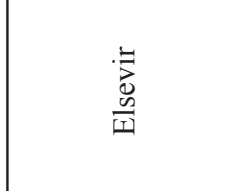 & 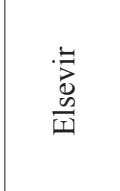 & $\begin{array}{l}\vec{J} \\
\frac{0}{0} \\
\frac{D}{D I}\end{array}$ & $\begin{array}{l}\vec{J} \\
\frac{0}{0} \\
\frac{n}{I I}\end{array}$ & $\begin{array}{l}\overrightarrow{\vec{d}} \\
\frac{\pi}{n} \\
\ddot{\infty} \\
\dot{\infty} \\
0\end{array}$ & $\begin{array}{l}: \vec{z} \\
\stackrel{0}{0} \\
\frac{1}{11}\end{array}$ & 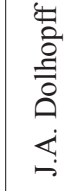 \\
\hline 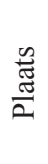 & 步 & 总 & 总 & 总 & 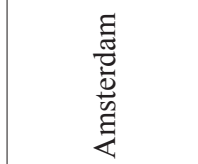 & 步 & 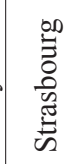 \\
\hline 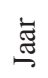 & $\stackrel{\mathcal{Z}}{0}$ & $\stackrel{\mathcal{Z}}{0}$ & $\underset{\mathscr{J}}{\mathscr{g}}$ & $\stackrel{\mathbb{Z}}{0}$ & $\underset{\infty}{\infty}$ & 疋 & $\stackrel{?}{0}$ \\
\hline 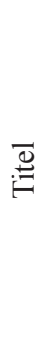 & 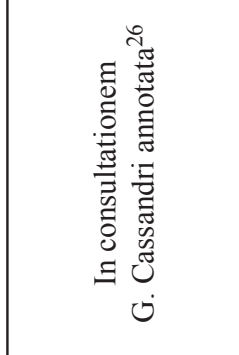 & 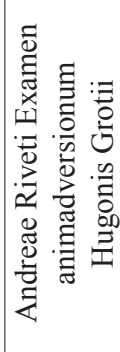 & 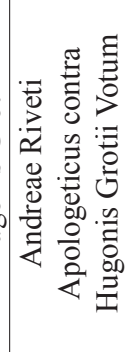 & 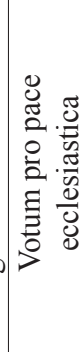 & 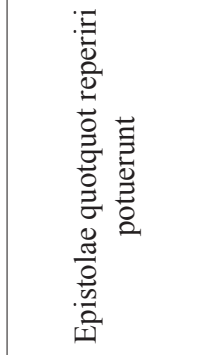 & 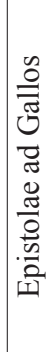 & 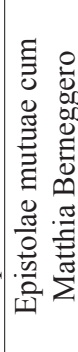 \\
\hline$\dot{\mathbf{z}}$ & F & $\stackrel{\infty}{\dot{\sigma}}$ & $\stackrel{\leftrightarrow}{\dot{q}}$ & $n$ & $\vec{n}$ & ถ่ & $\ddot{n}$ \\
\hline
\end{tabular}

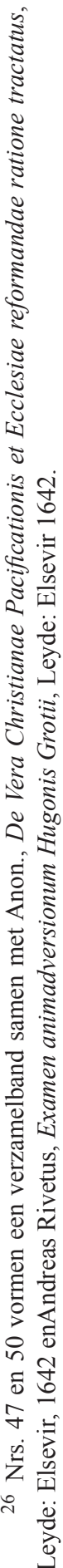




\begin{tabular}{|c|c|}
\hline 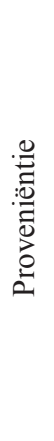 & 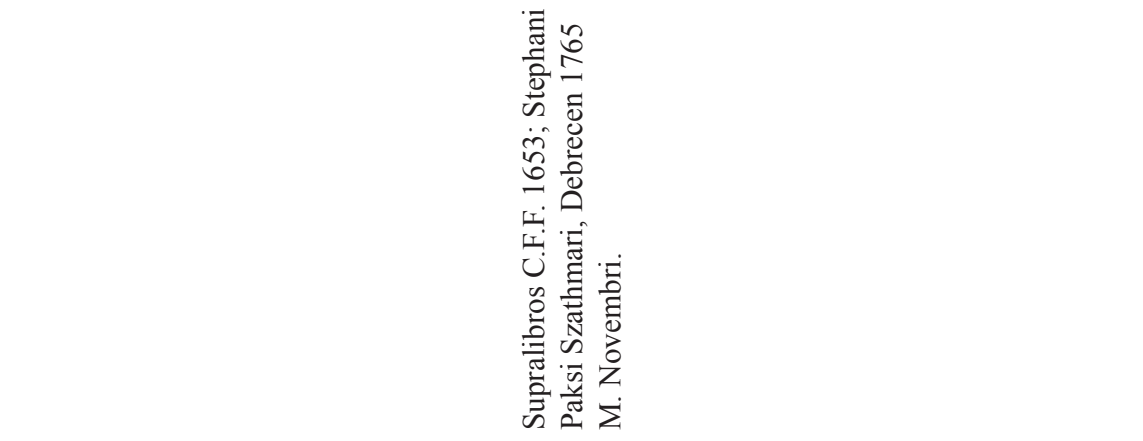 \\
\hline 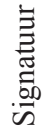 & $\underset{I}{\stackrel{J}{J}}$ \\
\hline$\sum_{i}$ & \\
\hline 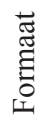 & \\
\hline $\begin{array}{l}\overrightarrow{\bar{D}} \\
\vec{D} \\
\stackrel{D}{0} \\
\vec{b}\end{array}$ & \\
\hline $\begin{array}{l}\frac{\tilde{J}}{\tilde{J}} \\
\frac{\pi}{2}\end{array}$ & \\
\hline 点 & \\
\hline 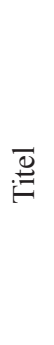 & 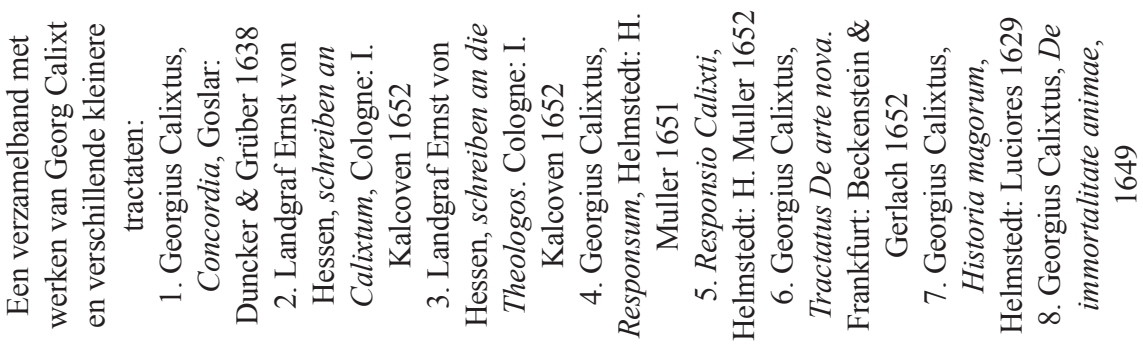 \\
\hline z & in \\
\hline
\end{tabular}




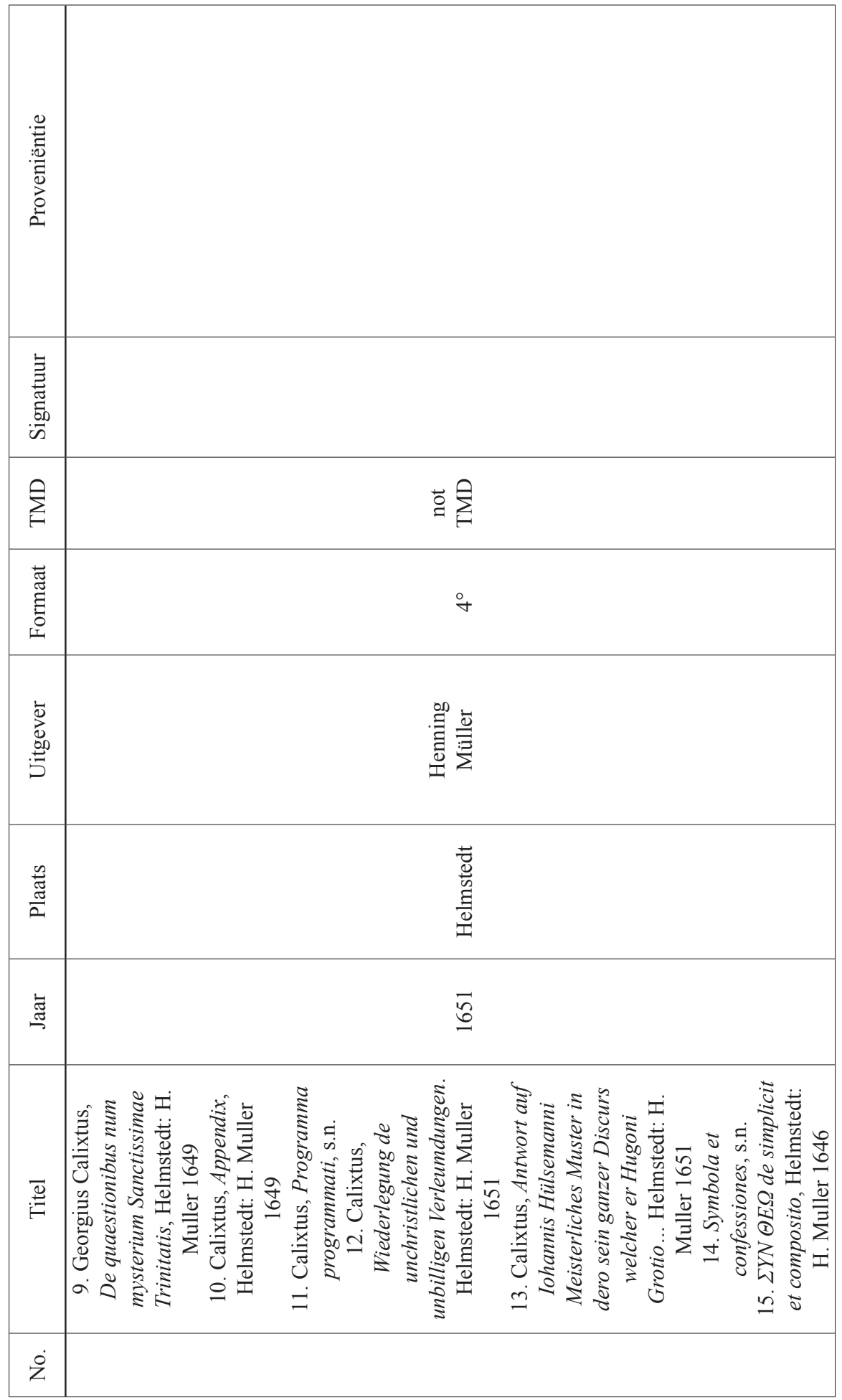


Jana Engelbrechtová $\left({ }^{*} 1967\right)$ studeerde in Brno Klassieke Talen, in 2003 promoveerde zij aldaar op De veritate religionis christianae van Hugo de Groot. Sinds 1998 is zij docente Latijn bij de Faculteit Letteren van de Palacký Universiteit in Olomouc. Haar interesse gaat uit naar de receptie van ideeën van Hugo de Groot en Nederlandse humanisten in Centraal-Europa, daarnaast houdt zij zich bezig met Latijnse literatuur in de overgangsperiode tussen Klassieke Oudheid en Middeleeuwen. e-mail: jana.engelbrechtova@upol.cz 